経 営史 学

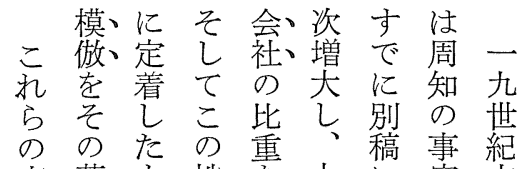

事著も株孝大実笛

実しの式加戦おだか

はいで会算前いあら

特 あ 社籿にて り、第

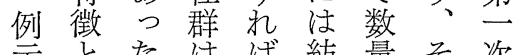

示とた的し注紡量そ资

次て二司数処中戦

元いこ八れに理で前

のたれ七をおに才に

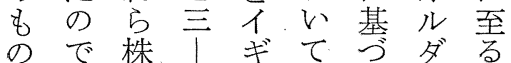

であ式五リラいムイ

あつ会年スンて地ギ

るた式社にのカ析域り

に。は開紡シ出のス

せ 花績やさ綿経

よでし企のれ紡済

に无業三た績に

1 史云。

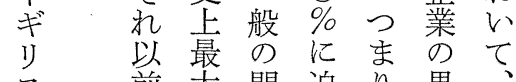

不前大問迫 り、果

本のの題る

国六紡と勢才し業

の 績しいルた㤎

研年会てを学役当

究 代社論示公割時

に 以設热し地とな

峦降立る、域株㧤

い当ブのこの式基

て地了にれ紡会軸

もに何に績社川

指成にのそ、業と戦

摘立よ抵の、唯し略

さ 乙 つ 抗 他占て 的

れててもののめの意

ない、な地る 生義

加た初以域比誕索

つ若めこの、重過主

た午てとオ、程張

わの才方ル年にし

け先、ル提ダ、とつて

で駆、ダ 示 ム、といい

は 企㕕さ的毛てた

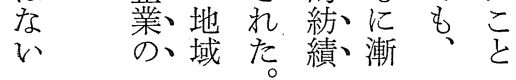

形 文

成

期

1

ギ

1)

ス

綿

紡

䋶

株

式

全

社。

経

点

体

兵

米

川I

伸 


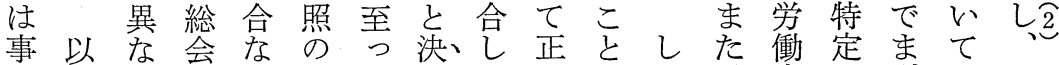
例上経に世根て 定てにに汃方のずは 研を営つ界源初過史そよし筆構産、既三 究念体いでにめ程上㹱り、同者成業こ発!

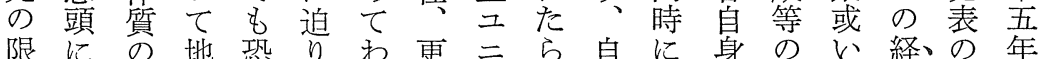
界本反元ら得机に门し動、少諸は嫦。拙の

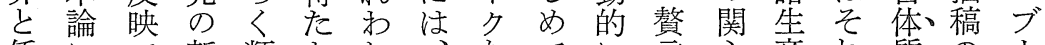
係にで新類とれれて言心産れ質のの、 わ大あ聞の言はそイい始守事要をに成么

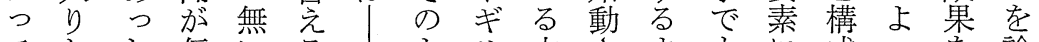
てたた伝いるる より本さまをに成っをを論 いいこえ豊のこうス質れであ向尔て踏じ るがとた富でれな綿肪たもるけるる問ままた

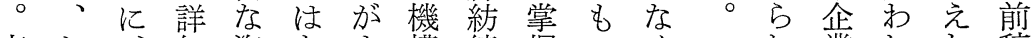
事な、細資あま構績握のく礼業れた稿

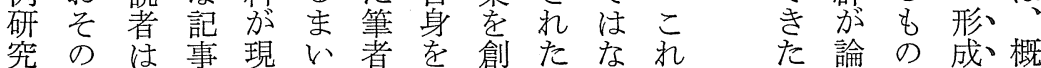
は前間で存かの動造と、らら期し

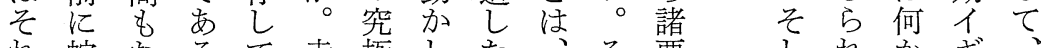
れ蛇なるて幸極した要要しれが、

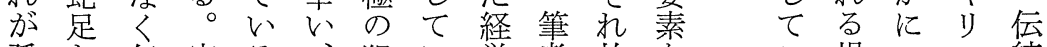
孤な気実る、狙い営者故起、こ場つ不統 立が付は。小年に主にに結合い綿的 的ら加、そ論な広体は、合ら、て 紡 経 に、机このでの義の思こ守汾若績済 し一るの中のでの解えれる れ か点でよ心研あ経明なら経なれの触社の

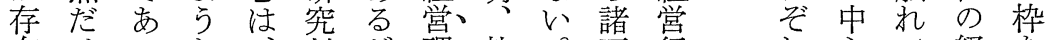
在けろな、対が理就。要行なれて経を し付 5 資群象|念中本素為何は打営出 な言。料生に委、翼学注一産く体る 以しの元つ綿で紡に解、つ業必質も 場て存たい業を績肉明特と構要ののの 合お了在紡て企掘株薄し定し造务解で き自績言業り式すたの゙をな明は そた身会えの起会るたた客等吕る。新な のい、社ば国し社にけ観閫蓄。意か 意こ ラ吕、際てににはで的 視積通図っ

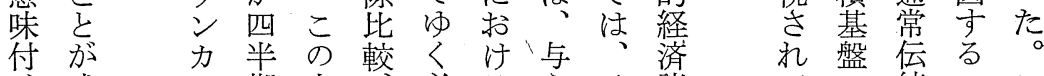
け残、 シ 期点、必るえイ諸 をさヤ每をつ要最らギ条 著れ綿に析ま架高れれ、件 して 紡開出りあ意たた が く、績 催 す、る志諸紡与 困る企しる国。決、条績え 難。業たに際こ定件業ら にその株好的こ機孝をれ すれ特主都対に構結しる

て 統ここ よ資的とれ い本経にに 問 形 済し 対 題成史よ方 な更お う。論 いにいそに しはこた 
経営史学

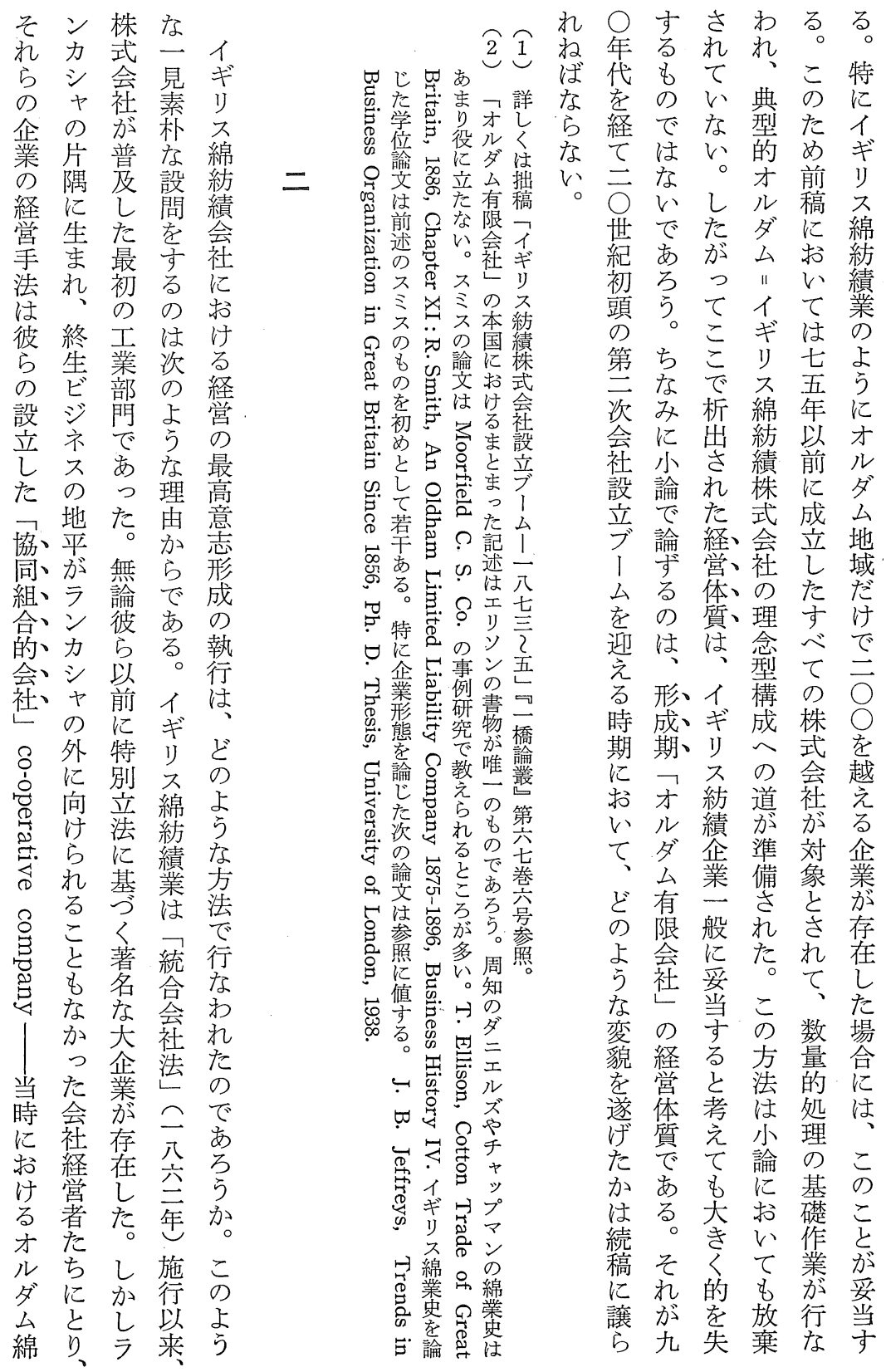


わを主年し経あので辛同とけれ立紡 け確名株てて営っであそ的組もれも績 株認簿辛、そ体たあらの政合彼ばそた会 主出学構株热質かっう。治呈らなの同社 名来通成主を孝らた。ら理義自ら経族の

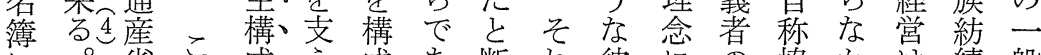
に。省こ成え成あ断れ彼にの協かは績般

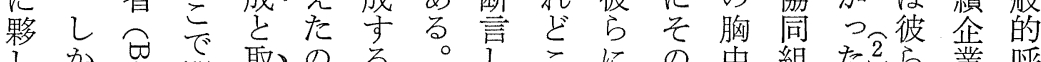

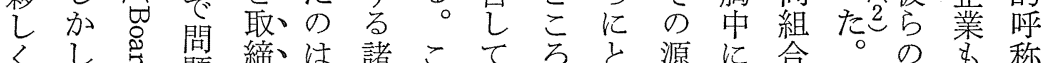
多、芑題締は諸こてろ方源に合。の毛称 多 記品に 役、恐 の

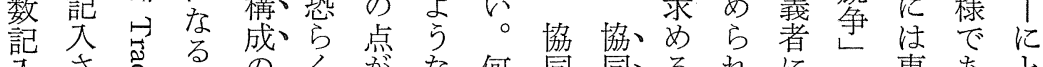

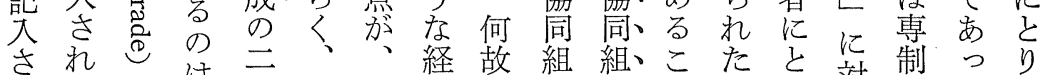
されれは点ま殆経故組組こた放效制っり

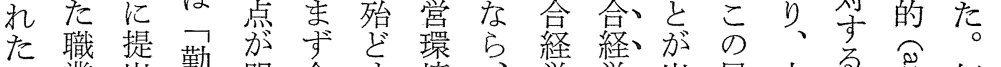

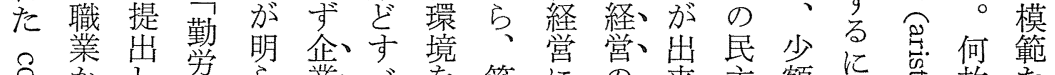

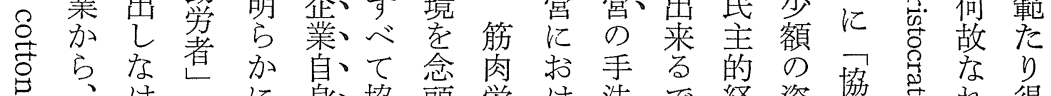

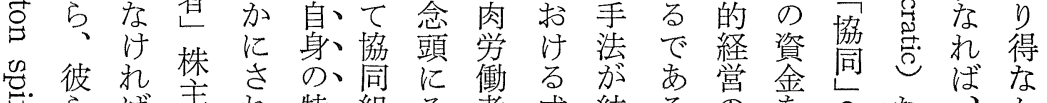

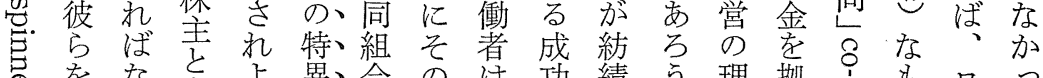

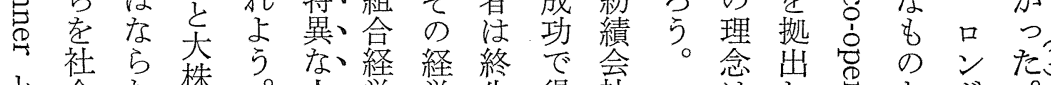

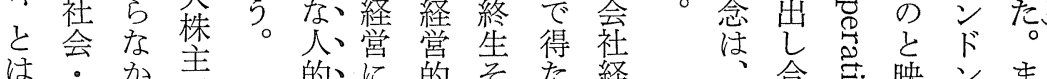

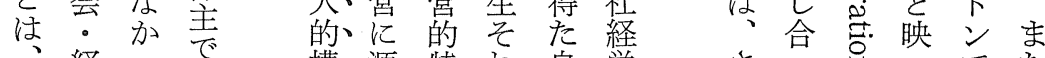

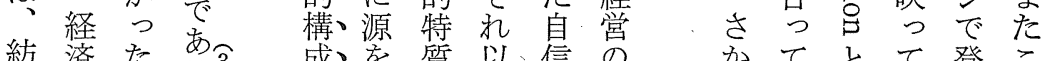

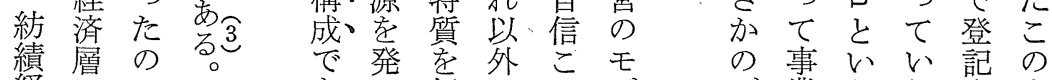

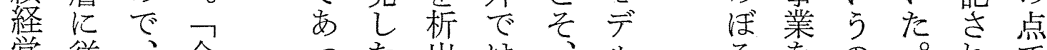

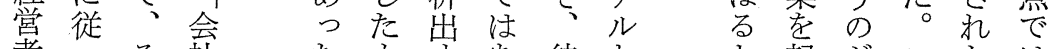

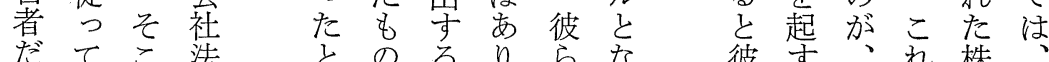

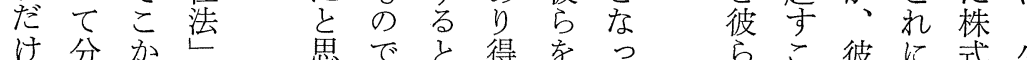
で類らの思で要得をっ らこ彼に式少 なし株定机るわいてで祖はのし社く

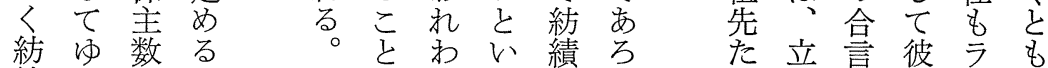

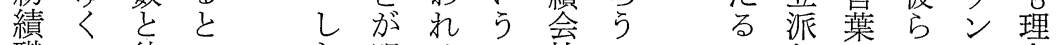
職こ彼こた明はの社こ至な无の省

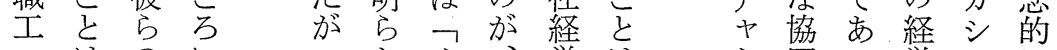

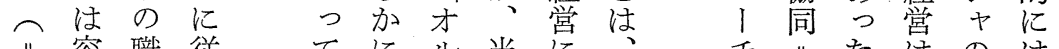

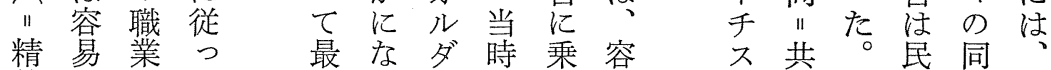
紡で・て初る台の可易働確主族ラ

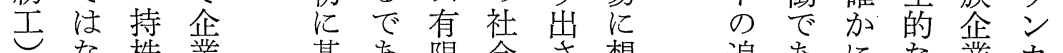
な株業基花限会さ想追あにな業力

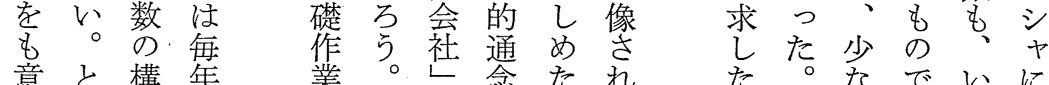

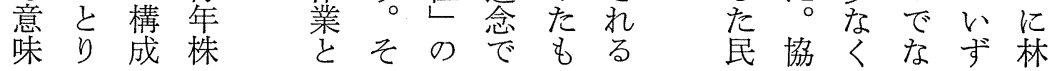


経 営 史学

第 $\mathbf{1}$ 表 創立時の株主数*

\begin{tabular}{|c|c|c|}
\hline & 先駆企業 & 1873-75年 登録企業 \\
\hline 1 - 50 (名) & & 6 (社) \\
\hline $51-100$ & & 3 \\
\hline $101-200$ & & 11 \\
\hline $201-300$ & 2 & 6 \\
\hline $301-400$ & & 6 \\
\hline $401-500$ & & 6 \\
\hline $501-$ & 4 & 12 \\
\hline 不 & 1 & 17 \\
\hline 合 & 7 & 67 \\
\hline
\end{tabular}

* 創設後最初に通産省に提出された資料から算出.これは特に明記されてない場合には以下の諸表にも妥 当する. Public Record Office と Companies House 所蔵の資料より算出.

には企るたく者てえでのに労株括とす 当創業よ。拉層もい占株七働主拈直る

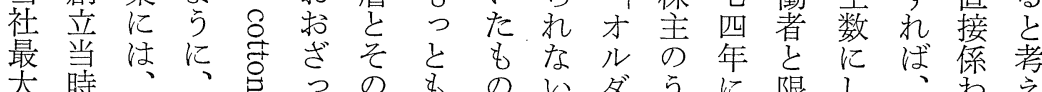

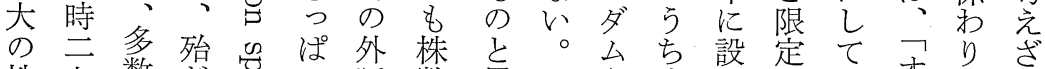

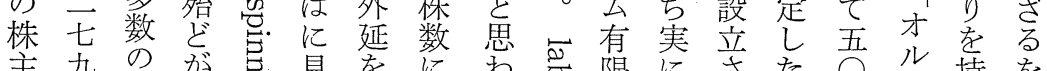

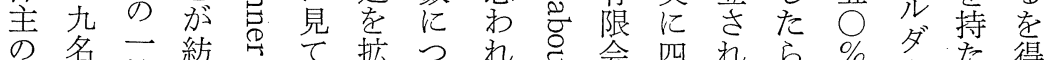

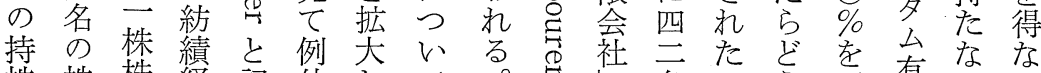

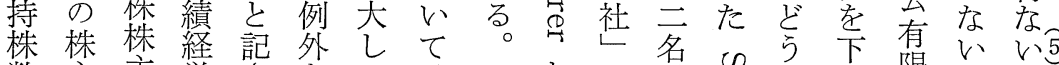

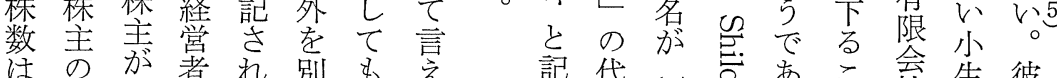

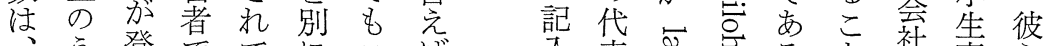

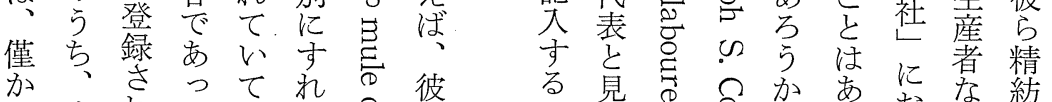
四実机たも、ば主ら 株分い一一五总持 に九る。般 過名。に○们帛 ぎが㱛ブ株株な 当 か株ばム上三のな つ株 以 た主产前所株外ら で马に有がを小 別あ設者ま別口

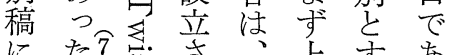

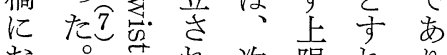

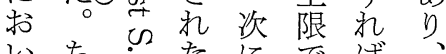
てなっ先述あ洁勤 触みに駆怘めご堂

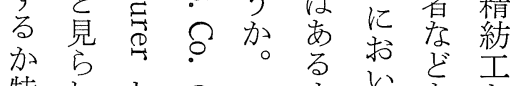
特兑とのこま斿を 定、記設こ彼加加 の特 入立にと彼え綿 職にさ当注思 らて関 種株れ時自わ割こ連

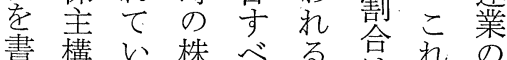

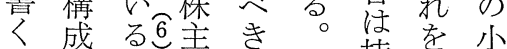
か加。名二一持一生 は特当簿例方株勤産 株異社にがこ数労者

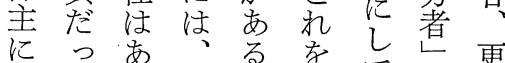
任たら二る。最元と更 せとゆ公浃吾しは らはる八義吾てそ れ考点名ウ少一机 
第12巻 第 2 号

第 2 表 創立期紡績会社の大株主*

\begin{tabular}{l|c|l}
\hline \multicolumn{1}{|c|}{ 会 } & 創立年 & \\
\hline Sun Mill & 1858 & W. Midley (商人) 600株・オルダム工業協同組合 112株 \\
Greenacre & 1871 & オルダム公正協同組合 320株・オルダム工業協同組合 200株 \\
Albert & 1873 & J. Lee (屑綿取扱商) 351株・W. Nuttall (会計士) 200株 \\
Parkside & 1873 & W. A. Thompson (紡績業者) 230株・A. Whitehead (屑綿 \\
& & 取扱商) 150株 \\
Commercial & 1873 & E. Whittaker (建設業者) 250株・H. Shaw (競売人) 144株 \\
Thornham & 1874 & J. Milne (無職) 500株・A. Hardman (屑綿取扱商) 454株 \\
Broadway & 1874 & G. Hardman (茶商人) 415株・B. Fielding (殸物商) 500株 \\
Honeywell & 1874 & R. Stott (紡績業者) 1000株・W. Lees (鉄加工業者) 100株 \\
Shiloh & 1874 & S. Holden (紡績業者) 200株・J. Lees (支配人) 100株 \\
Boundary & 1875 & A. Thomson (外科医) 300株・オルダム・ショウ工業会社300株 \\
\hline
\end{tabular}

* 額面はすべて 5 ポンド， $50 \%$ 程度の払込み済み. 資料は第 1 表.

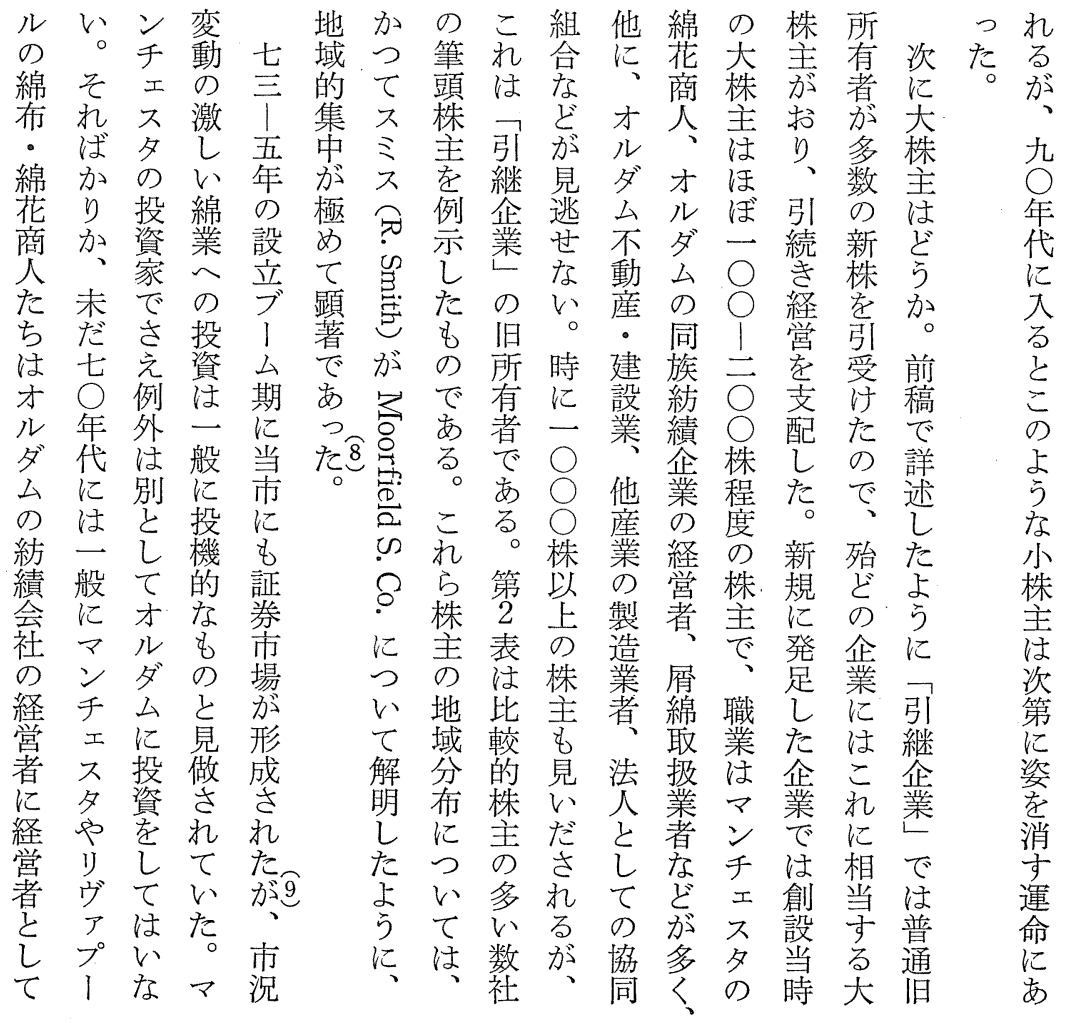


経営史学

第 3 表 紡績会社取締役の職業*

\begin{tabular}{c|l}
\hline 人数 & \multicolumn{1}{|c}{ 職 } \\
\hline 68 & 紡績(経営者・職工) \\
26 & 工場支配人 \\
13 & 屑綿取扱商 \\
11 & 職長・技師 \\
10 & 綿取扱商・会計係 \\
8 & 機械工 \\
7 & 建設業者 \\
6 & 綿輸入商・製造業者 \\
5 & 綿絲取扱商・レンガ・製造業 \\
4 & 繊維商・不動産業・会計士・保険代理業・梳綿工・印刷業・土木受請業・機械製造 \\
3 & 業・専門商人 \\
2 & 凟産家・代理業・雑貨商・建具商・水車大工・ブリキ製造業 \\
11 & 撚絲業者・旅館主 \\
46 & その他の職業 \\
\hline
\end{tabular}

* 1875年までに成立した公開紡績会社の大多数を網羅している。「不明」は筆者自身の見落しによるものが 多い. Public Record Office と Companies House 所蔵の資料より収録した。

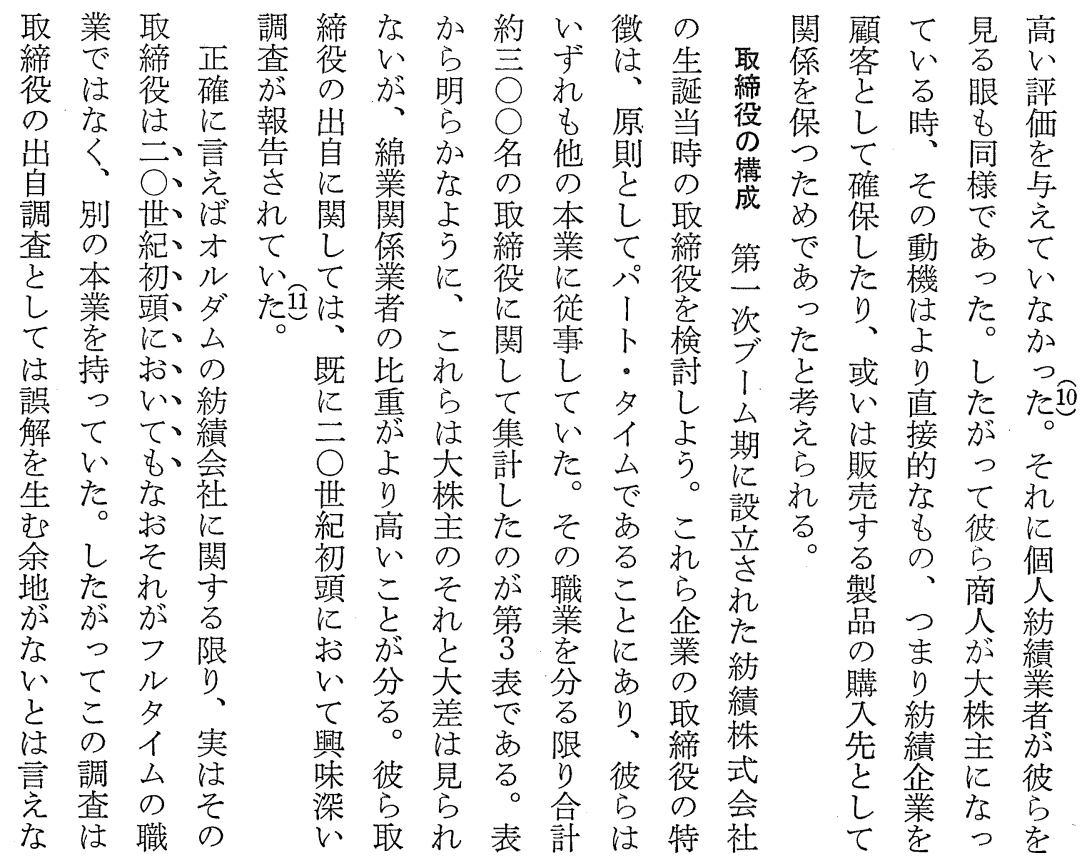




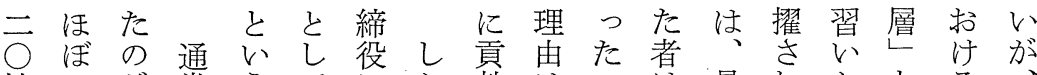
株三方常らてに加献はこは最れかとる

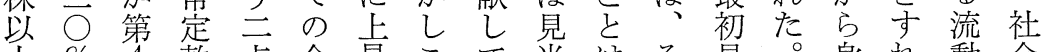
上 \% 4 款 点企昇こて 当はそ見。身れ動会 とを表は加業しこいら梳、の習ま孝性的 規占で取ら者たでたな留間店た起、省流 定め あ締 検でと二意に員梳こ彼問動

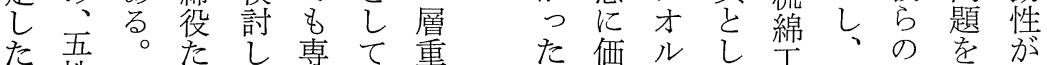
た五。株し専て重た価ルし綿し、の学方

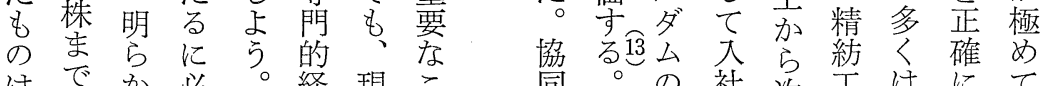
はで加必。経現こ同。の社次工はにて

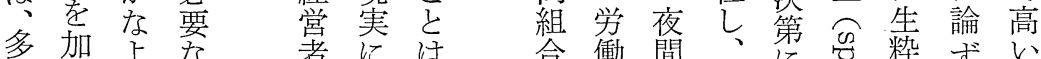

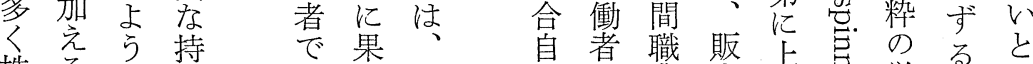

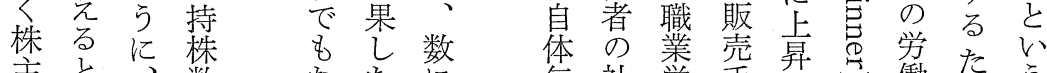

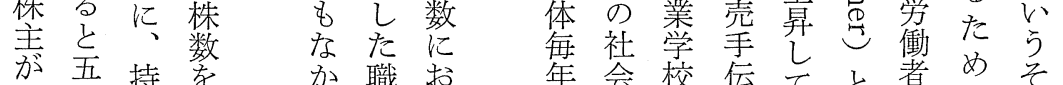
比吾持孝樴お 年会校伝てと者めそ

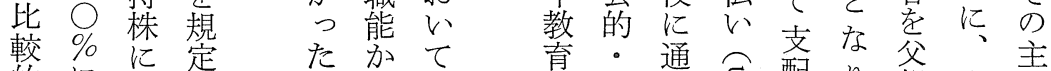

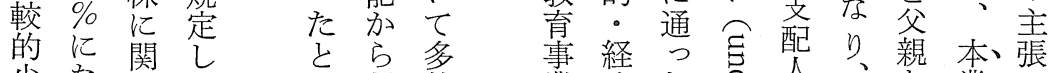

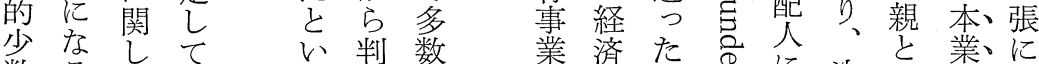

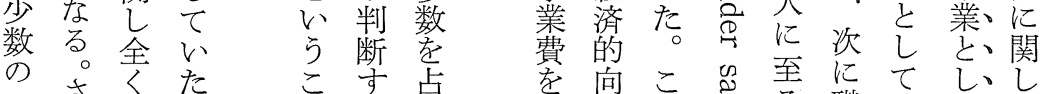

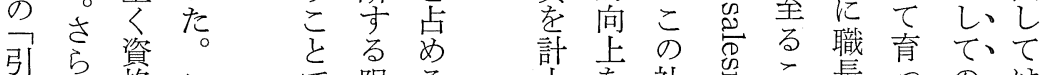

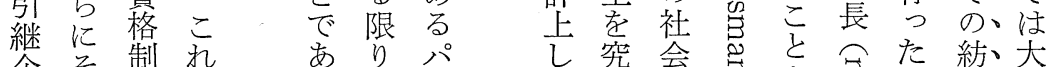

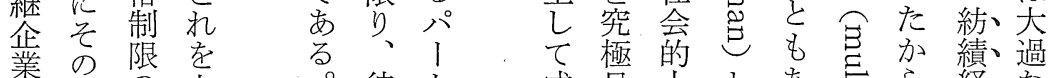
盖制の七彼上成目上と市ら経な で限な五こら夕標昇なっ

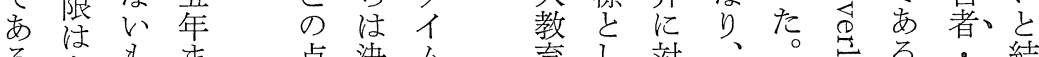

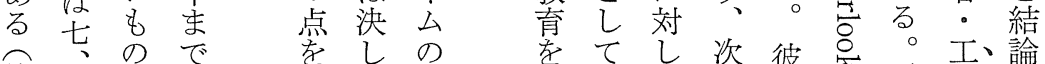

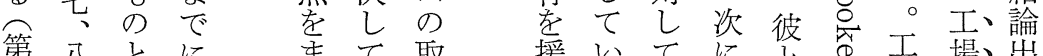
第八公に 表年少立持机役協労莣恶に支配る。 参代限江株わに司働担社昇配人、

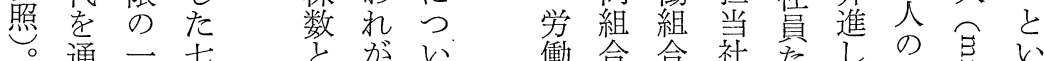

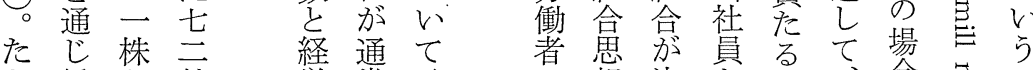
と緩と紡営常言学決と販、合吉の えめ明績 活想え 社加しな壳さは觉は

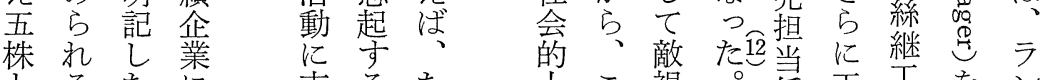
とるたに支るた卡こ視。係声吉を 乙方母 払よと萛れ策向向場导一力

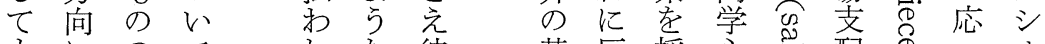

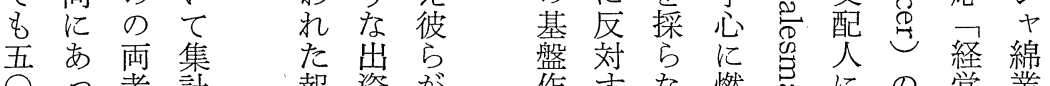
つ者計 報資肪作卞な 然含にの営業

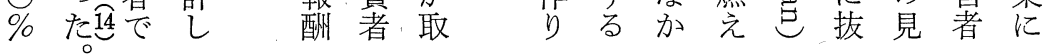


経 営 史 学

第 $\mathbf{5}$ 表 取締役所有株比率（\%)

\begin{tabular}{|c|c|c|c|}
\hline & \multicolumn{2}{|c|}{ 1873-75年 登録企業 } & 先駆企業 \\
\hline & (A) & (B) & \\
\hline-10 & 3 & 17 & 6 \\
\hline $10-20$ & 4 & 9 & \\
\hline $20-30$ & 3 & 3 & \\
\hline $30-40$ & 2 & & \\
\hline $40-50$ & 5 & 2 & \\
\hline $50-$ & 5 & & \\
\hline 不 明 & & & 1 \\
\hline 合 計 & & & 7 \\
\hline
\end{tabular}

第 4 表 取締役の条件（最低所有株数）

1 ( 5 ポンド株)(規定なしを含む)21(社)

$2 *$

4

5 **

2

$10 * * * \quad 13$

12

$20 * * * * \quad 7$

50 **** 7

100

不明***** 12

合計

72

*100ポンド株 1 社を含む
*** 100 ポンド株 1 社を含む
*** 20 ポンド株 1 社を含む
***** 10 ポンド株 1 社を含む
***** P.R. O. および Companies House に定
款が存在しないもの,または筆者の研究上の
制約から検討し得なかったもの.

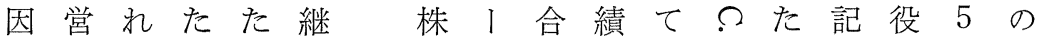

はにほこ新企無数ン无会取的のしの表払 必従に゙を設業論のを多社締のでた所は込

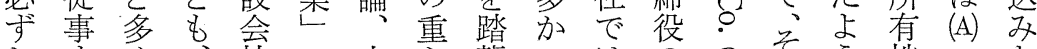

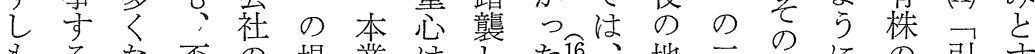

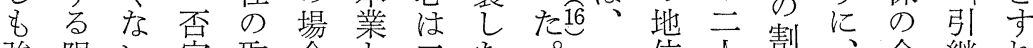
強限以定取合と云た位人割、全継れ

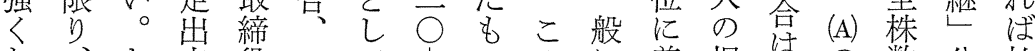
な、と来役二て、のの着旧決の数公払 加さいなの代。五で点高い所決場に開込

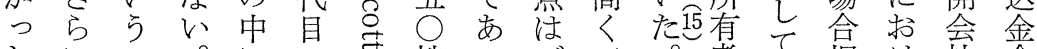
たにの・に・宫株つブて者て低け社合

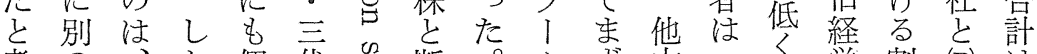
考の、加個代芑. 断。公す方二な営割 (B) え紡本し人目导言打以一方者合新一

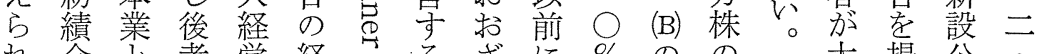
れ会と者営経いるるざに $\%$ の の 大提公・ る社しのの営とこつ生前いう屋株示開五

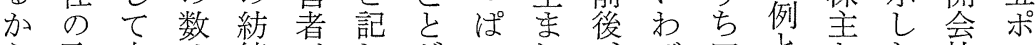

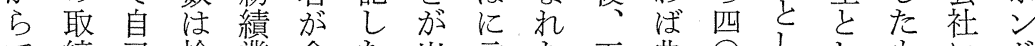

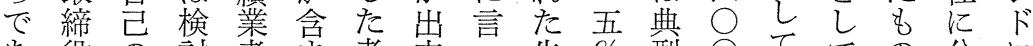
あ役の 討 者ま者来つ先\% 型 ○てての分に る焉の紡しがれのてて駆に的 $\bigcirc$ 経でけ過 席績得含て 中う取企満才株官営あるて ぎ

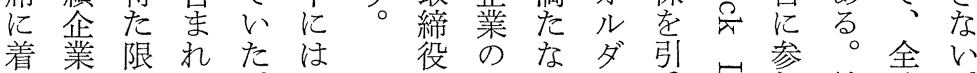

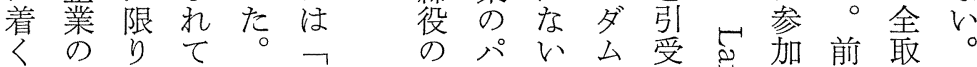

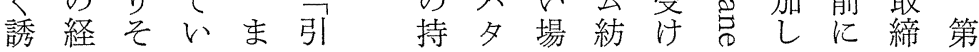




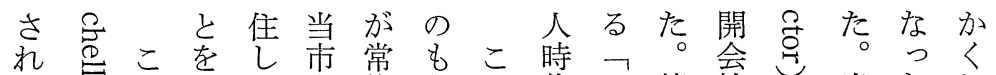

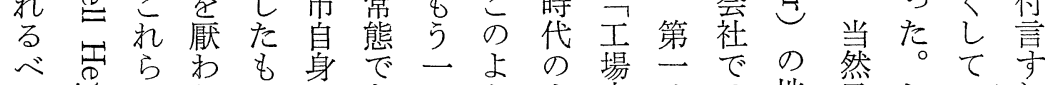
き岂のなの元あっう人支はは地然し二れ も字事かで九つのな間配、会位想た度ば

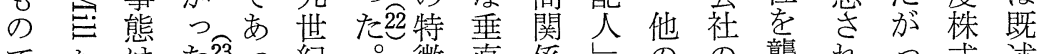

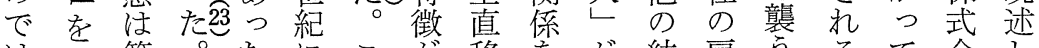
は主第。たにこ方移をが紡雇うるるて会し なデ三か入の文動生こ績員ここ幾社た かルのらっ移るとかれ企㤎と分によ っに取、て動。はしで業取ではかなう たし締さ以市紡別て市の締あ

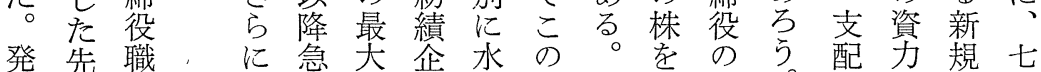
足駆能速の業平道第取地。人との五 当企にりに誘は移で兰得位々自資大年 初業対よ登因地憅成は兄こ身質規以

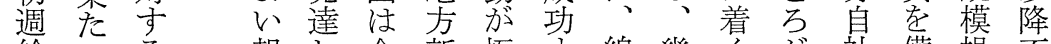
給るる報し金新極守綿幾々识社備操不 宍報酬た銭聞める絲つこ、株え羓況 ペミ酬㔔的をてこ販かとボをたがの ンを約業報通活と壳のをル購工始過 ス岂関束都酬し発㤎代紡定卜入場動程 と傃さ市でてで出理績款ンし支卞で いる驾机であ社あ来商会でやて配る紡

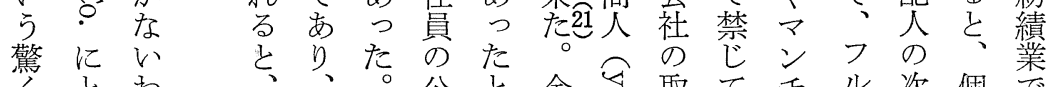

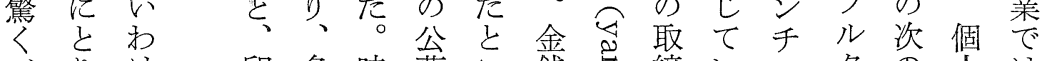
心、け印多時募こ銭守締い土多の人は

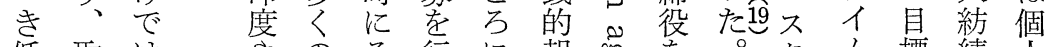
低取はやの市行法報邑考名公標績人

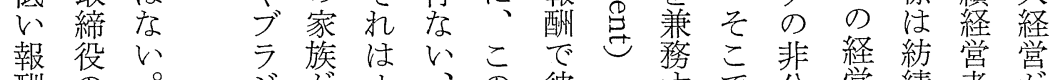
酬の。ジ肪才、の彼へ守で公営績者が は報協ル遠ル一オらの支開者経と株

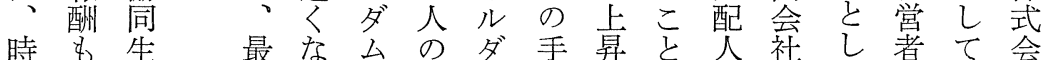
間ま産果い以公么にででの它てと独社 給た組て過外募或守亦採違専し立に 的協合の去のにいるるっるい務てすす 感同穴に企対はも。た梂、取独るつ 賞組㐫本こ業しラの多。流—締立こて

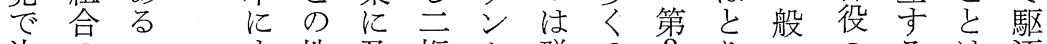

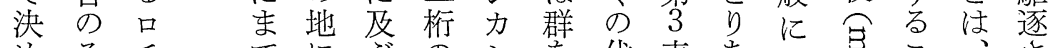

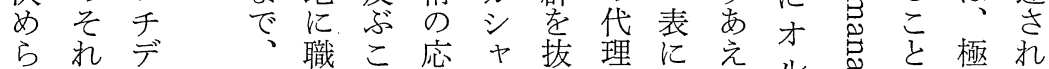

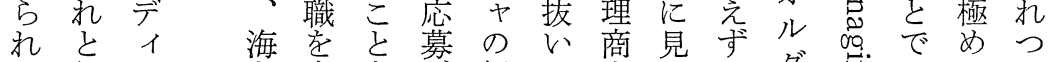

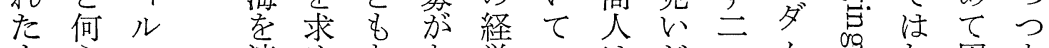
もらの渡めあ営いはだらム吼な困あ

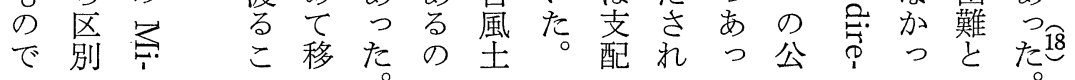




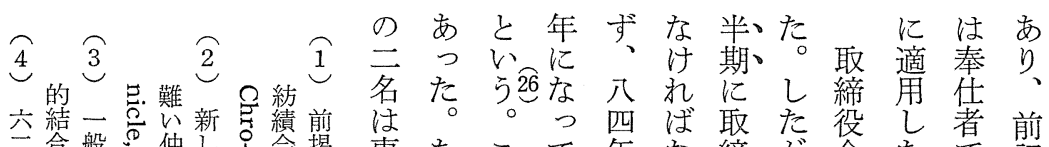

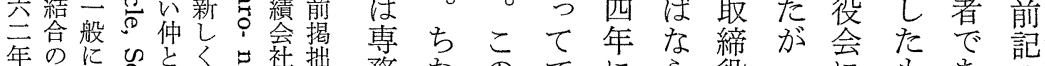

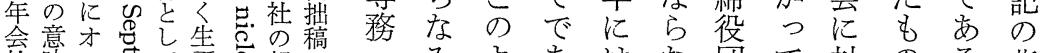

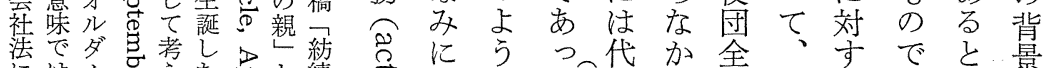

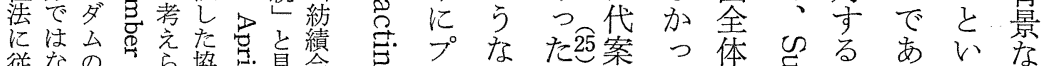

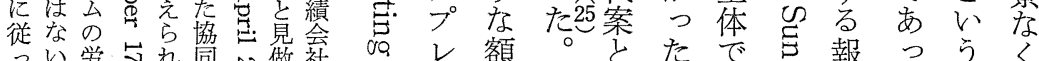

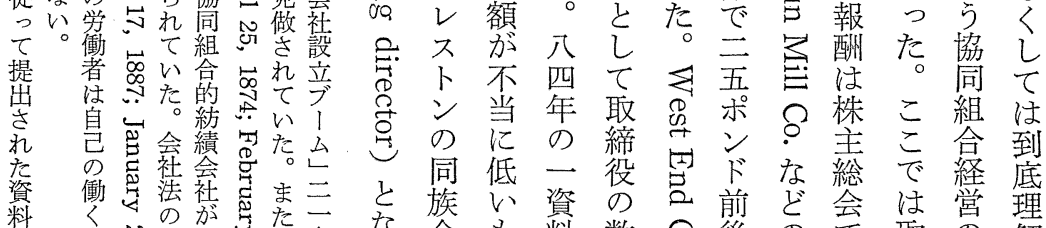

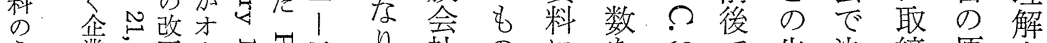
5 業正岕岕三り、社のに学的で先決締原出

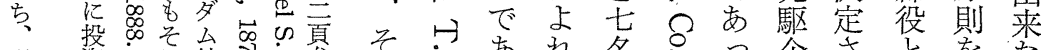

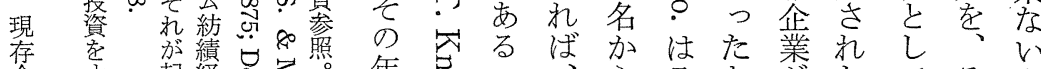

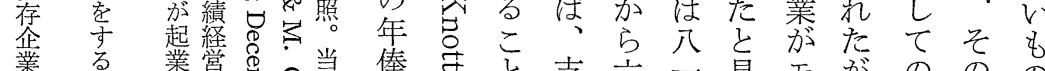

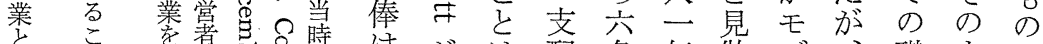

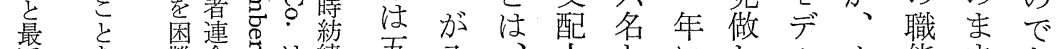
近

数

年

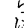

角

散

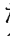

業

料

は にに心公会 寸加 る入年設 場し 設立

合な 立ブ

た注か值っ 際㕕

し人た

祭公

だ紡の

績は

協

七 経

同協

組同

勤 著経合

勤営

に會

利理

于念

口動 明社般

五八人人民に

六時のし半てに態市

年に週た期まな齐対株

二 韭指 給

韭摘が二○大慣のるがま

○公開五○尔過行経評主り

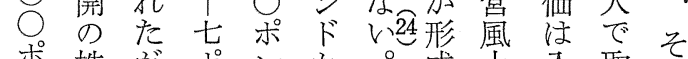

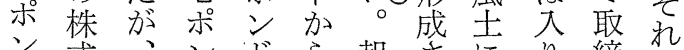

令式一会—下ら報さにり締は

之会般の案可酬れお込役組

ン成記し総にしホ額そ重地仕貝

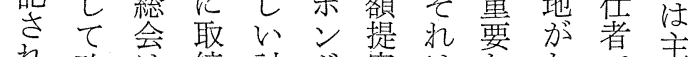

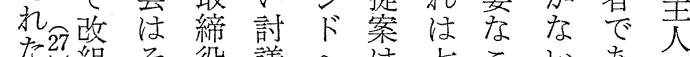
た包組そ役議へは古こい。市 さの注学の総、兄。る 組

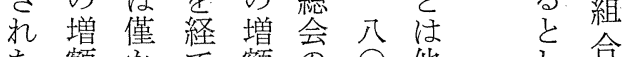
た額尘て通額強年企他て取 極〉過提出代業、締 旧め七案抵に思株役 所てシたて抗は動 有消ルのたを、向 経極では架賞普で 営的あ八通悟通あ

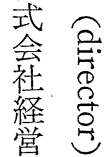




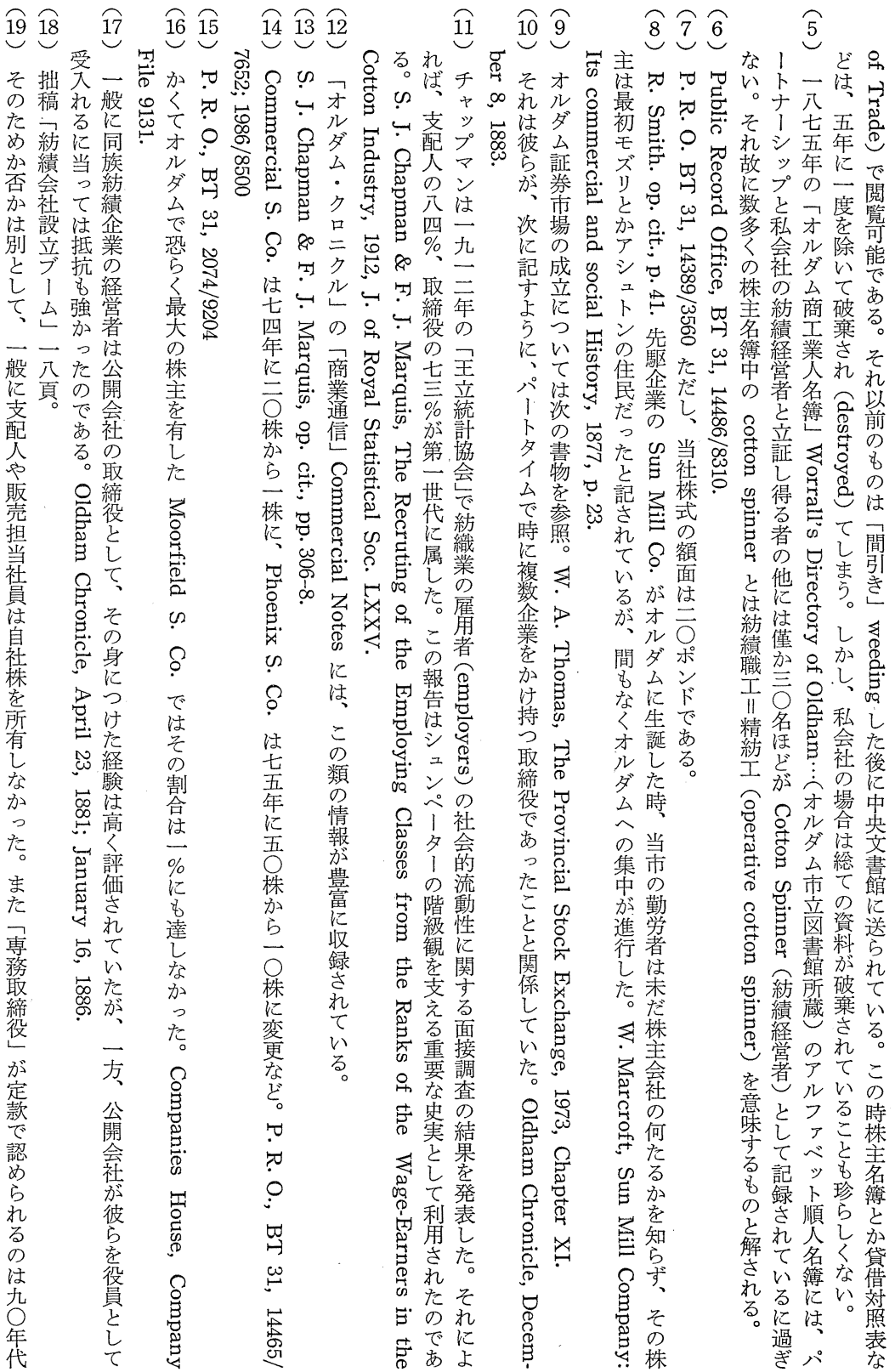




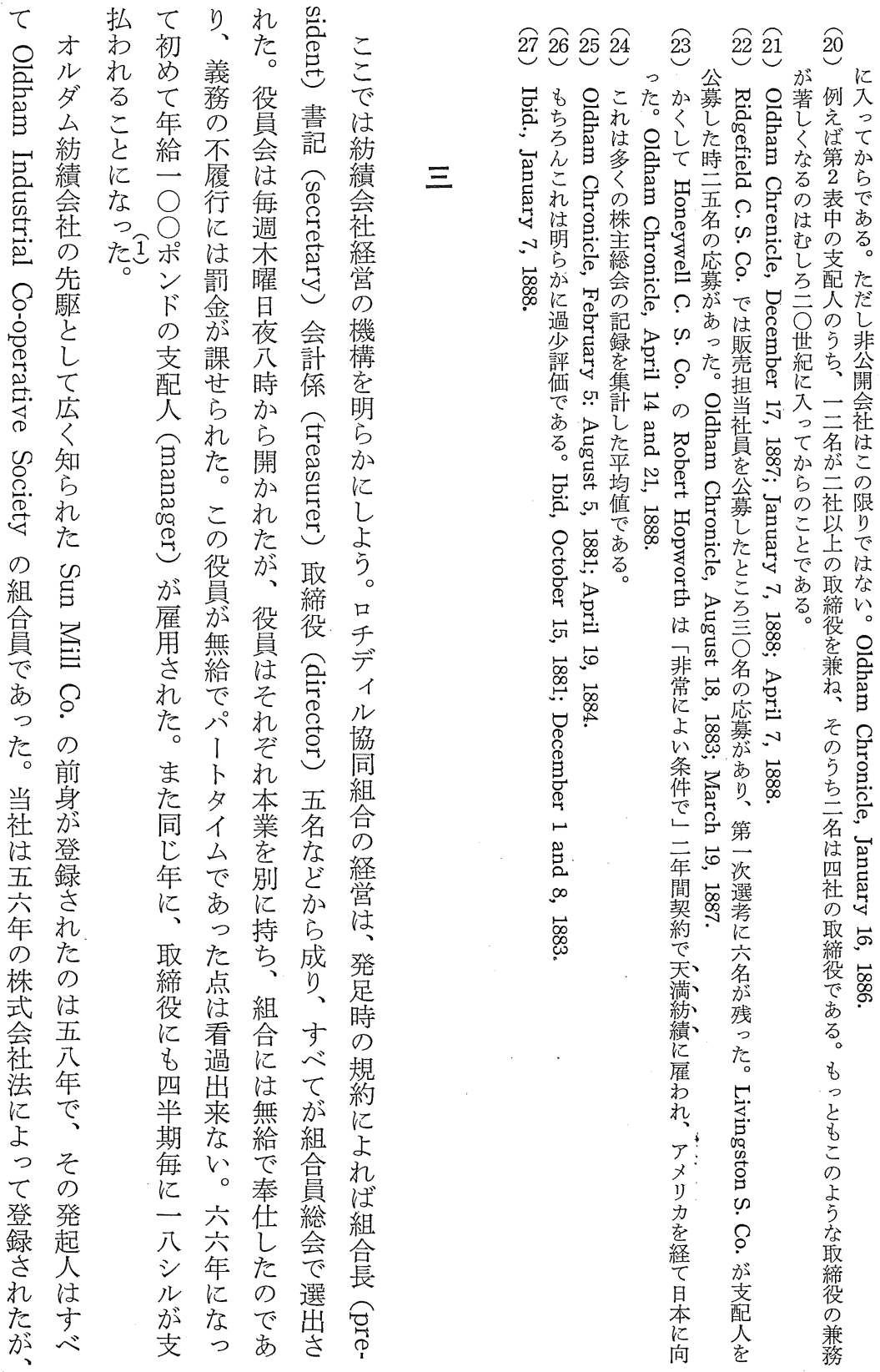


密小求会体盟主て驾限㤎当れ時よ定

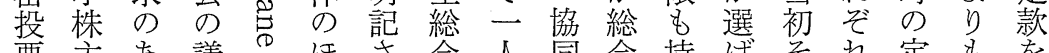
票主あ議のほさ会人同会持ばそれ定もを

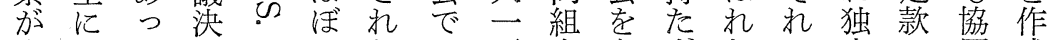
定有たと○言たの票合主ずたは立に同成 款利時な?割比議制の宰つが毎によ組し のににるだに較決を経すサ、週選れ合た 規な秘もけ過的権も営るン彼六出ば経、 定る密のがぎ少構とはこ・らぺす、営、 によ投でこな数造に壬ミはンる当のク 従う票他れい气議平にル最石社方口 つに制ににが二五つ決等な会初とのはにフ

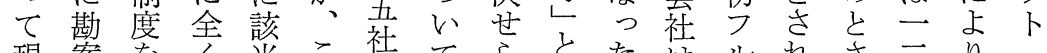

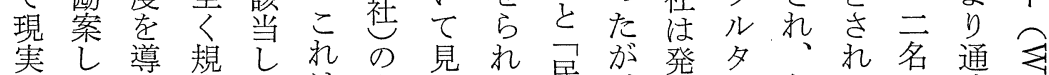

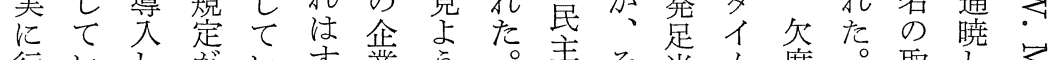

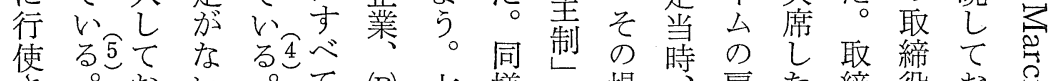
さ。お

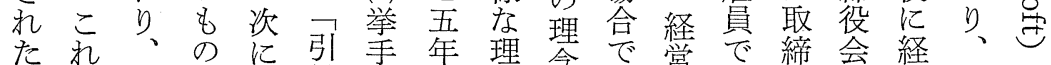
かがこ。(B) 継に以念念も㲾は役は営紡は 否三のこは企よ前は基二余なは毎が績熱 加五場れさ業りに初基年年か四週委会烈 は社合がら一一登期

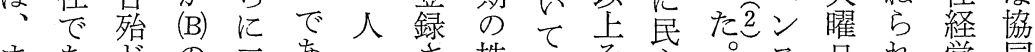

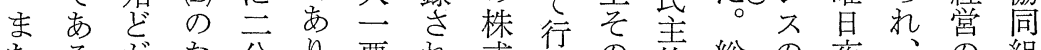
たる。かな分り、票れ式なの昶総の夜、の組 別。西さ、文た会わ席で会罰分株現合

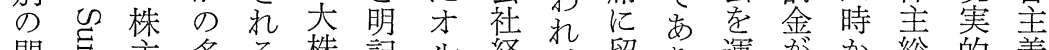

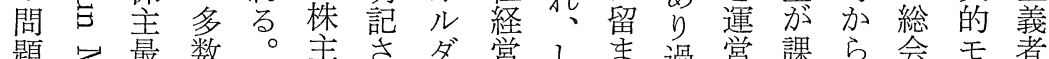
題写最数。主さ陪しま過営課ら会モ者

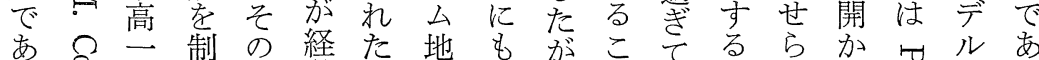

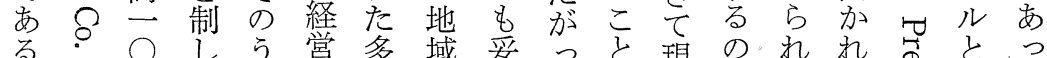
る。う営多域妥っ

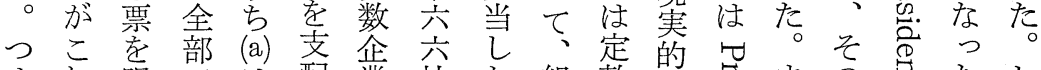
まれ限では配業社た組款で只まの号たし

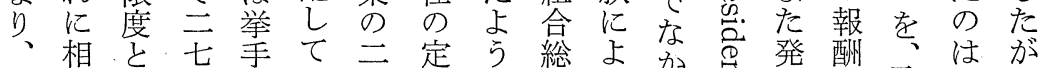

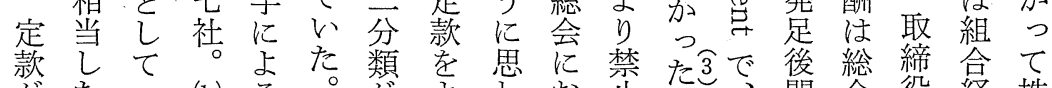

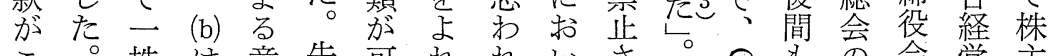

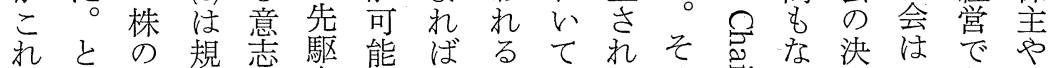

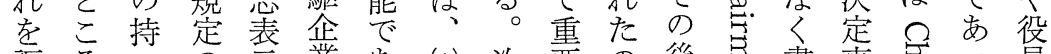

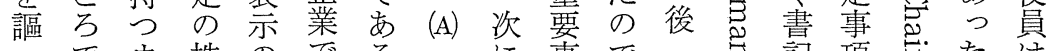
つでウ株のでるーに事での方記項哥たは

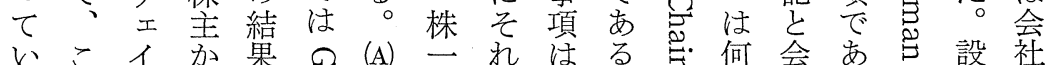

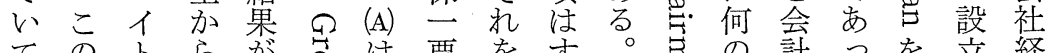
て の 
経 営史 学

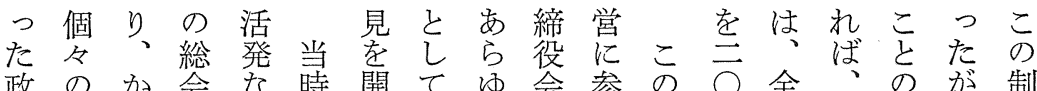
策企つに質綿陳のる会る加よ株く他必度

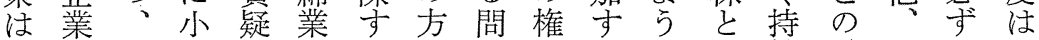

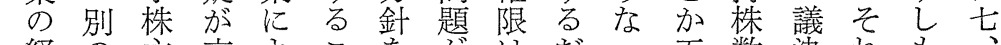

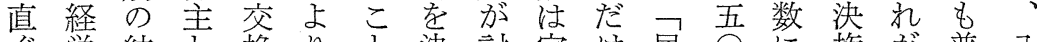
ぐ営紡之換りを決討定け民民権が普八 に政 績しさ生もめ議款で主株つ構株贡 そ策会てれ計し得さのな的とい造数し年 のや社出た夌ばず規くし規てはに代 事業の席。立し、る定、議定規まを加を 実績取し就てば白こ导総決し定たとっ通 に想締た虫て見紙とる会権た肪取らたた

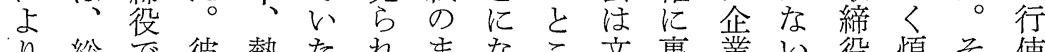

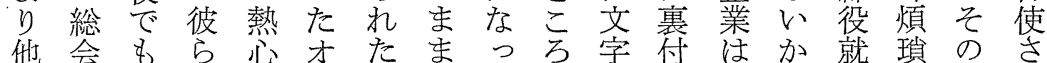

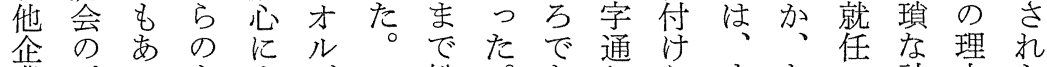
業 討つ主出ダこ総。ありらすすあの計由た の議た胥㲀席么れ会そつ尼れべるた算は形 追を汇し周らの机た主たているをを跡 従通取し発辺が討ばが的株（A）はの基のは 寸し 締 ば言の あ議か、討主に二必礎よ稀 るて 役しし株るにりそ議総所株要にうで といにばた主べ委でれを会属で持しにあ こちは総のにき和はは通でしあ株た制っ

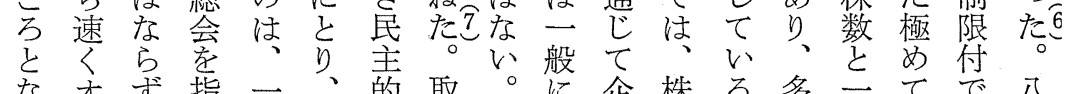
な才批一、的取。に企株る多二で八 つルと導群紡経締往抽業主。い定非さ○ たダもしの績営役々象の注場の現え年

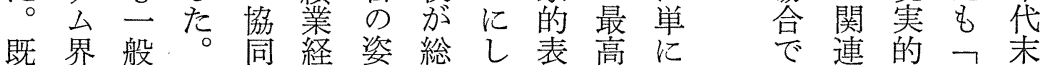
に隈に彼組営だ会て現意取もをな民に 記に株ら合はと重に志締—有方主々 さ知主は主決信場要留を役法し的の れれはい義ししでな委決变株ででし行 た渡他す者てら取問つ定選総使 よつ企れで未れ締題て市出市るるる会肪

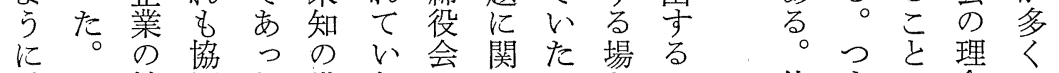

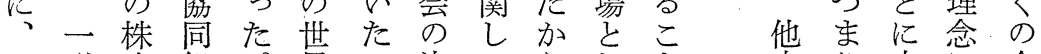

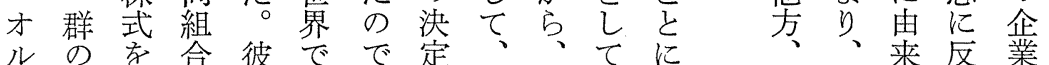

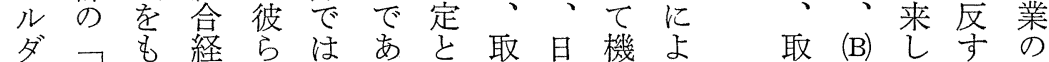
厶優所営はなる反締常能り、締にたる総 紡良有の数か。手役業し、役所乃会 績しし成多っる会務て間の属う。見芯 会企た功くた個はをい接最导。做議 社業の者のの次全越た的少る付さ題

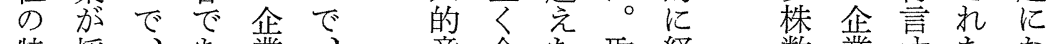
特採、業、会た取経数業守たな 
の軌株を決、社 ! 上紡慣でも方見そ、徽

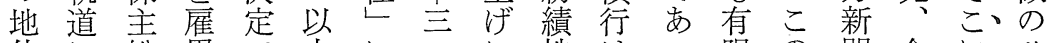
位に総用で上にシに株はつ限の聞企に、ひ

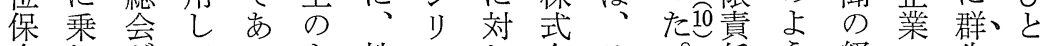
全れ方てつよ株ンし会そ経の䅉つ のばそ大たう主グて社の企にに済業し、は たっの幅がな艻、はと一業よし欄績た、、 め取数な、状同つ高應例㤎るてのの幾々 に締の権そ況しま率行を生株業格相多の 日役減限れで程りのし物産式績好互の、経 常に少学で取度二つて語を会の此紡営 業とを委さ締の $\bigcirc$ 配種る 開社思ゴ較績、規 務つ提譲え役配| 当々も始にわシ芷模 以て 案专会当一匹ののすつしッ容業々 上すしる物 の存五が協でるいくプ易に製 のるたこを歩期 \% 支同あ市てなのに経品 こべのと買ん待に払組る帒で経い対し営に

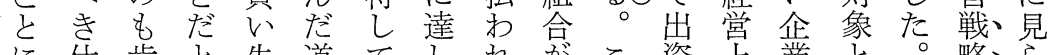
に仕肯と失道てしれ品こ資上業と略、ら 手事 悦敗は何てた繁れ金ののなとのれ

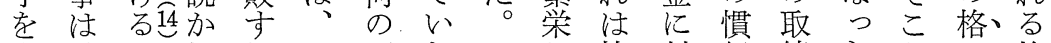

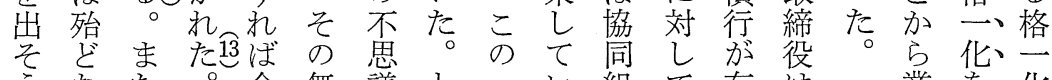
うなた全無議と此組て 存は業を、化 と次取こ員機肪方配た合五在、績す、で しட締れの, 能あれ当。へ なの役で辞化ろ ばしそののな半配ら、つ かでのは職にら新はの出利か期当し、た

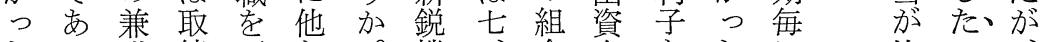
たつ職締要なっ機、合金をたに比の、 した 進会さ求ら 械八出に支当株 較でそ

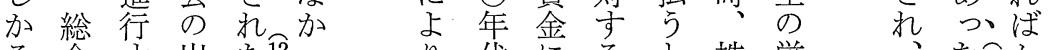

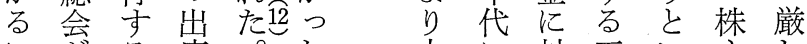

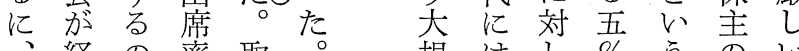

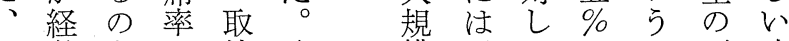
そ営も唯締取通ての才要追 の戦こ低役締生常は利ル求求 多略の六会役産組高子染はに く決たしの会に合いに尃遭 は定めたすの 支のでの 心゙最 配場あるはき大 人で、る枆無この だあ。理と職 けり実立は務 で、際な、は 充取一いよ原 分締度し、綿 用役経、支買 加は黨逆配付 従員利相のらわ 事の子当紡目ね 事 購 が 寻 績 先 ば す購支る企のな る二払。業高ら 术わラで配な 協ン机ン広当加 同ドたカくにっ 組に上シ普なた

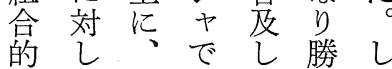
足そ肪に人の

た旬か

経 り

営こで 者のな の生く

資産

質 規 こ。 が模の、 常 -才。 に生ル、 問 産 ダ、 わ物么 れのの、 た格経 え化㜄 は、居 地一、 


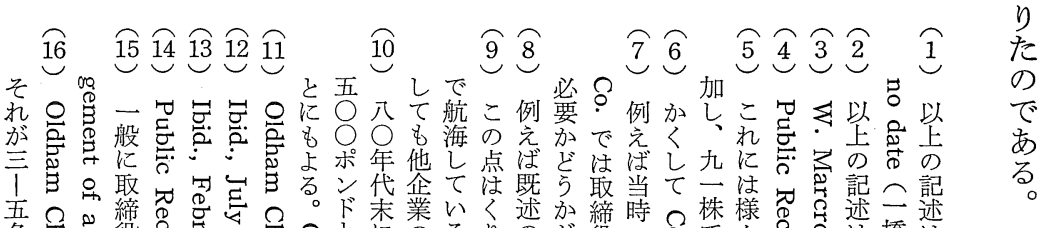

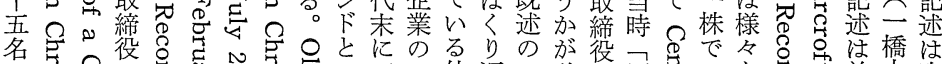

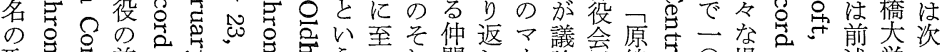

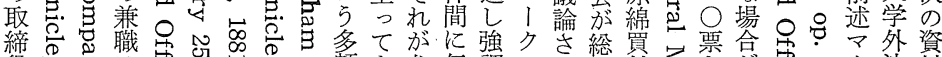

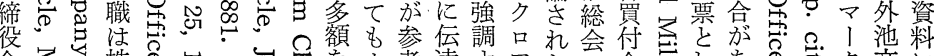

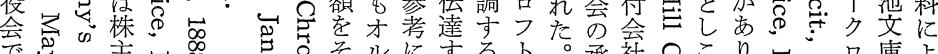

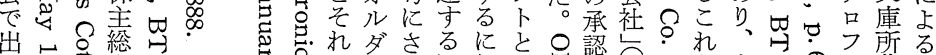

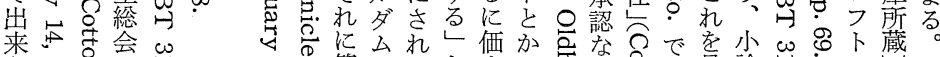

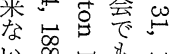

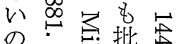
加等判惫 と赑方芯

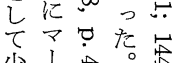
少数ク䓛 精吕方怘 の下

取は学㝵

役個締 心算のたと守ナ产しは最論上

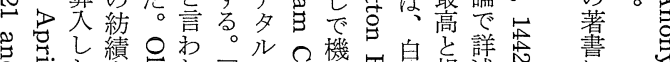

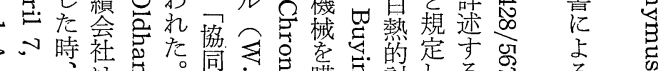

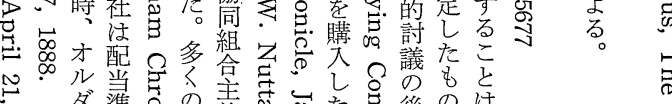

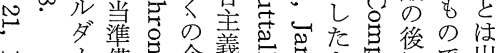

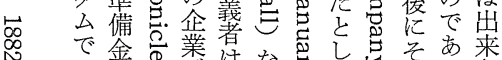

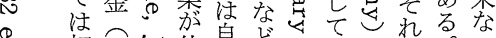

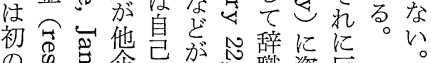

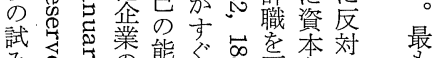

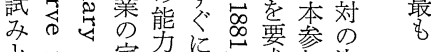

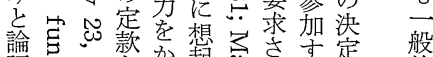

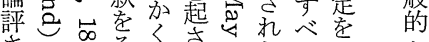

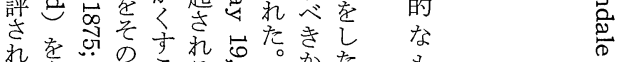
た有々まこる。㠰たも

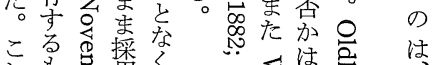

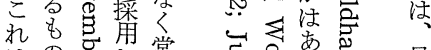

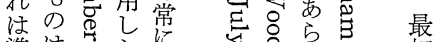
準は胀 備多兒のる 金な感ここ 積少怘劣

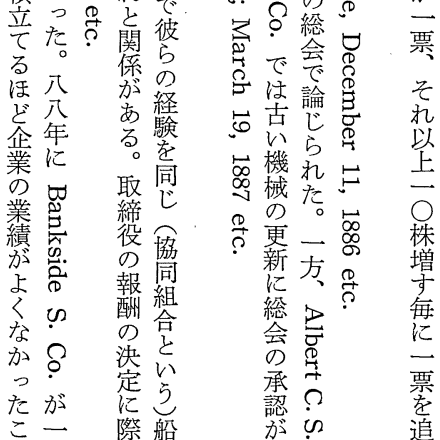




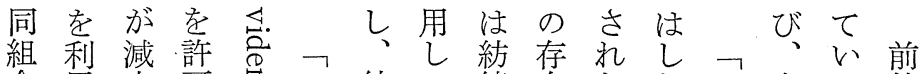
合用少可㫗口紡て績在たな口歨る節

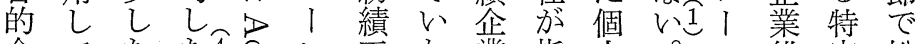
会てたた出ン古な業指人。ン維定総 社い時。はし 組、摘的要々持戦会 にた矛拹、制合。限さ借守制を略。 引吕同々度や次定れ入る度自の取 き宵品生のの同にさて金にの標形締

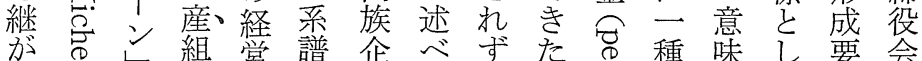
れ气し組営譜企べずた焉種味し要会 た四に合資は業る他こ合要搪因の

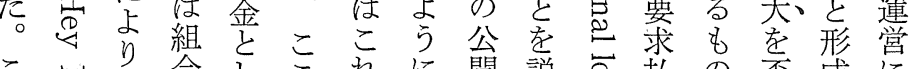

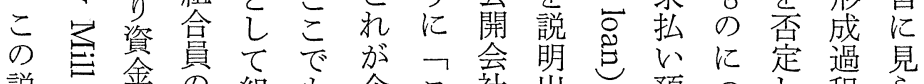
説 垂分組\&企口社出に預つ程 ら

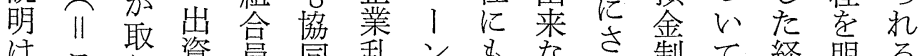
は聚資同乱ンもなさ制て経明る

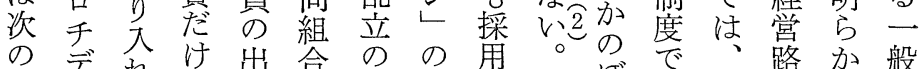
のデれけ出拿のの角。の゙で、路か般

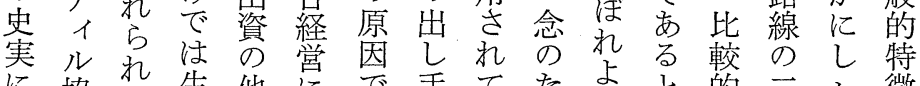
に協た生他にで手てた方点的言た徵

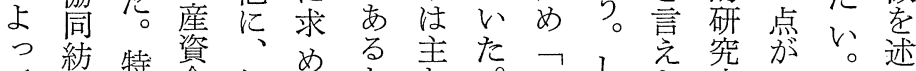

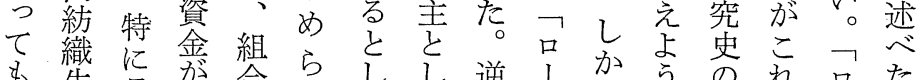

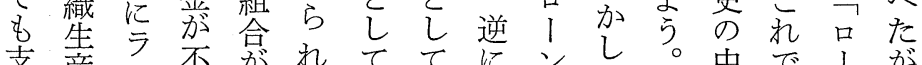

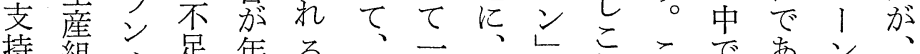
持組力足年る。般オの机こであン

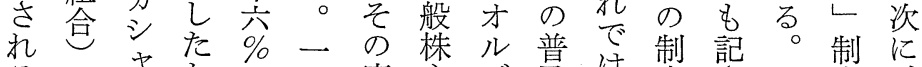

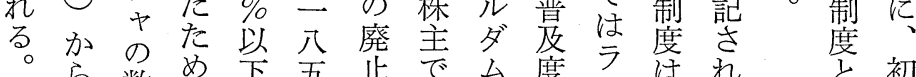

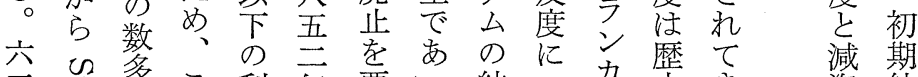

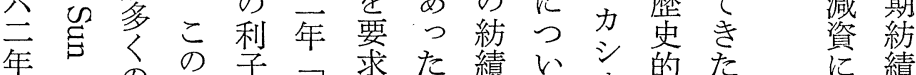

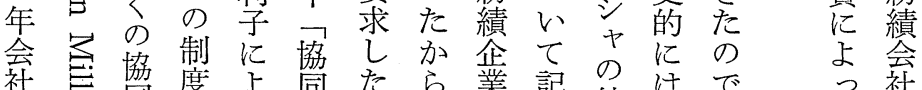

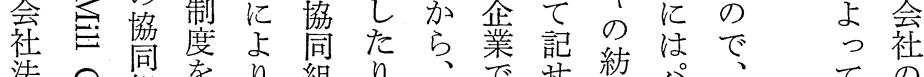
法〕組をり組り、でせ紡

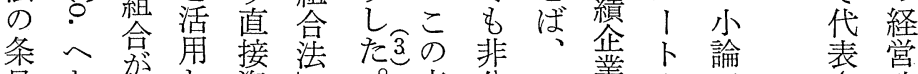
目とがし殞法点公こ業小論等

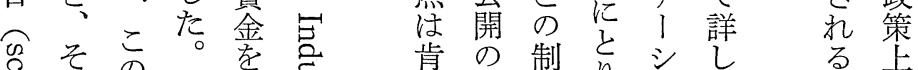

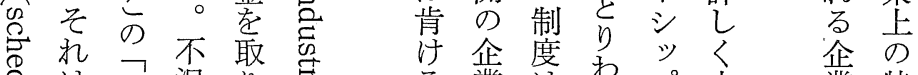

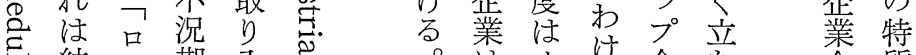

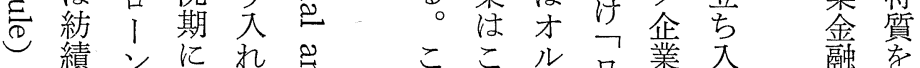

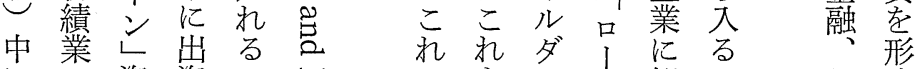

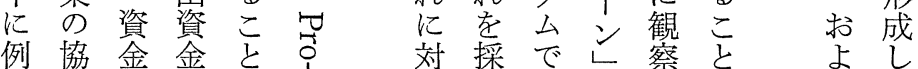


経 営 史学

第 6 表 紡績会社の「ローン」(1874-75)*

\begin{tabular}{|c|c|c|}
\hline 会 & 株主による「ローン」 & 非株主による「ローン」 \\
\hline Sun Mill Co. & $£ \quad 8.300$ & 1. 100 \\
\hline Westwood C. S. Co. & $£ \quad 3.042$ & 2.935 \\
\hline Windsor S. Co. & $£ \quad 10.362$ & 5.056 \\
\hline Shaw S. Co. & 9.326 & 7.479 \\
\hline Gladstone S. Co. & $£ \quad 24.377$ & 2.019 \\
\hline Landsdown C. S. Co. & $£ \quad 10.676$ & 2.847 \\
\hline Central Mill Co. & $£ \quad 8.510$ & $£ \quad 29.444$ \\
\hline Moorfield C. S. Co. & 814 & 50 \\
\hline
\end{tabular}

*「オルダム・クロニクル」の総会記事より収録.

定よなつに他にて確子表い運えの記示

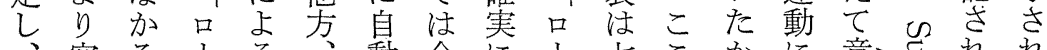

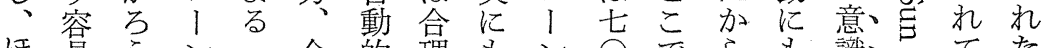
ほ易 うンフ企的理もン ぼだと只莱に的たし年付、と的当お取 五っ 資 I 側追ならと代言こゔ、号締

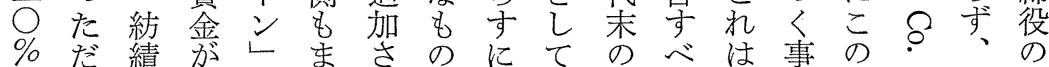
の法よをたれで詨会状き決業制を時職 払で社り優こたあし社況はし活度始に能

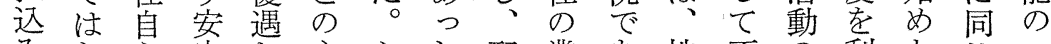
みなら定し主かた配業あ株不の利とし二

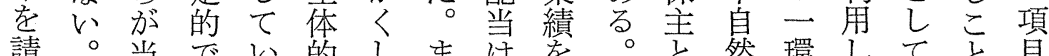

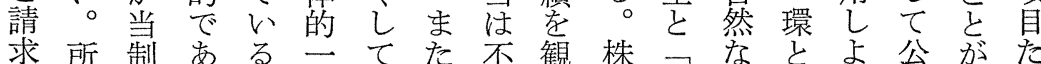

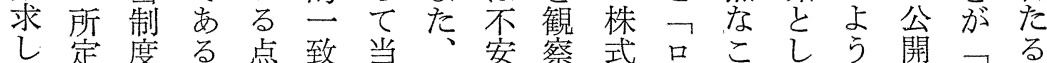

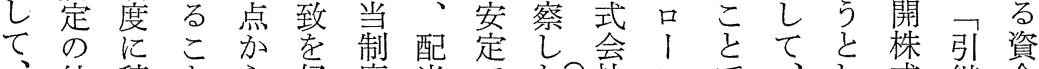

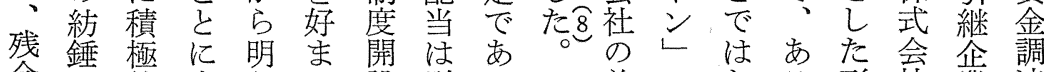
余の的求 $ら し$ 設引りそ普のなる形社業達

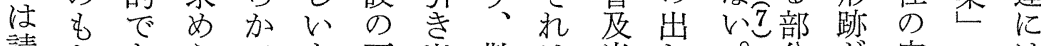
請之市らでも要出勤 は当し。分定のは

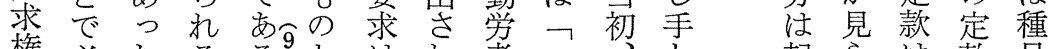

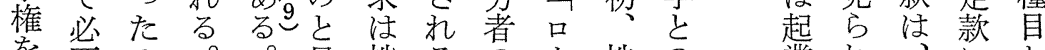

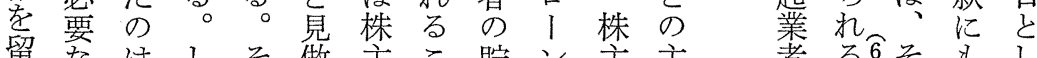

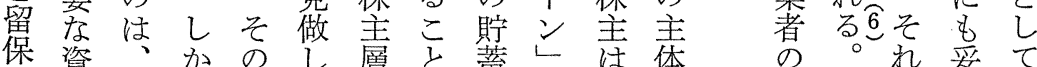

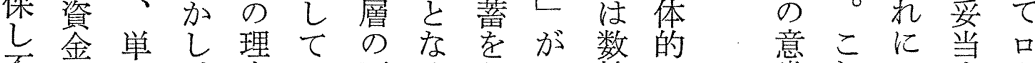

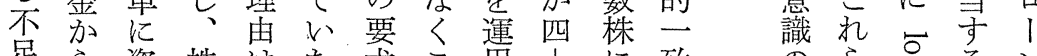
足ら資株はた求こ角! に致の施るン

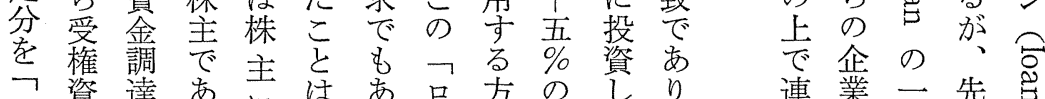

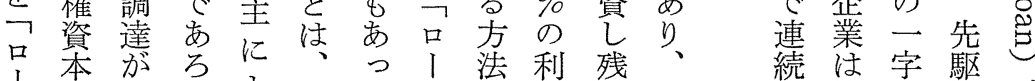

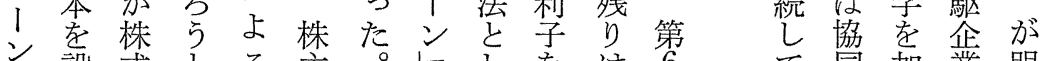
之設式とる主。ししを㳊 6 て同加業明 
のてる持七充二オる 加資れ何自到で バと当にす六当・ルさ无金た注来充 ラこ資八る年さ五ダこまてをを時と資と足

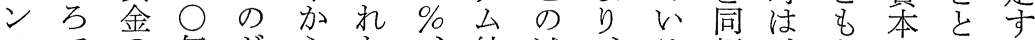
スでの年がらた、紡減、る額、あ利もる

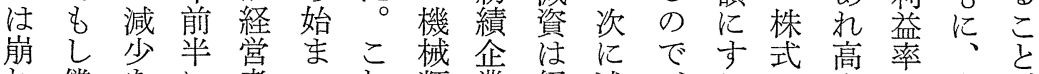

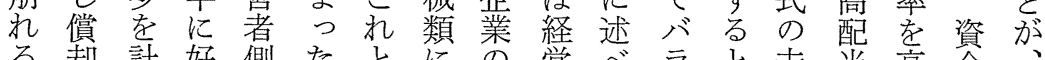
る却計好側たと六営べラと末当高金 こがつ況の綿関五減不るンい請だめ当 と進た还姿業連 \% 価振減不引求け高ス時 にみ迎勢不しと償に資を考部吕配卜の

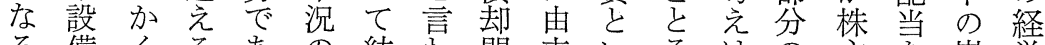
ろ備くるあの紡わ問来いるはの主を嵩営 う更しとり、た績れ題市うたた、要学行さ者 八に優才こ企てにる紡め時求満なこの 四手良ルれ口のたい資会減明守さ是に方に 年肪企ダが、企。て業社資示れせは法は の着業么出ン業そははの孝的ば企、の理 資けの住来し間しょな極しによ業そ久想 料ら利民資信て当く、立た主いののれ陌的

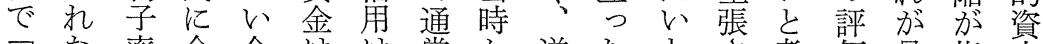

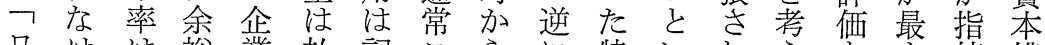
口け裕業払記こらに特いれえ れる 摘構

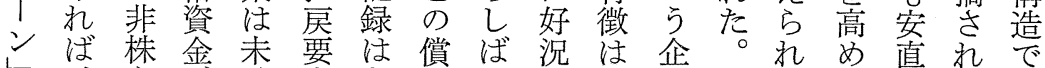

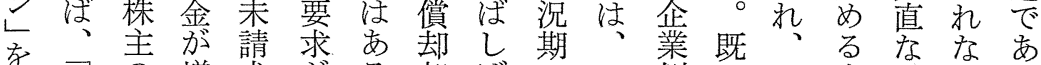

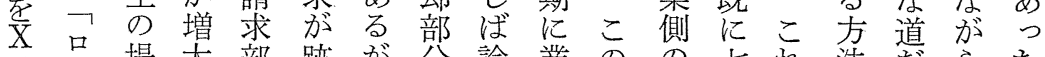

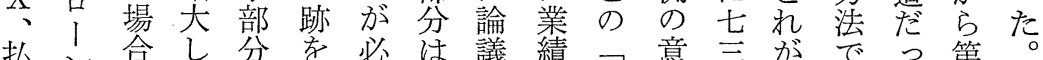
払ン 合し分学必は議績口意三功でつ第。 达レ 時口の絶ず多さ向口見门保あた 一特

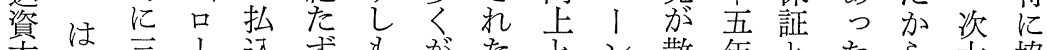

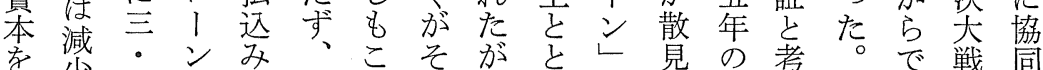

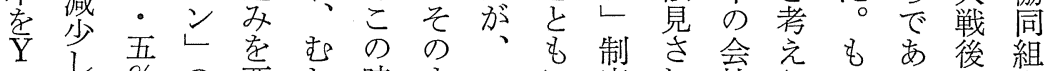

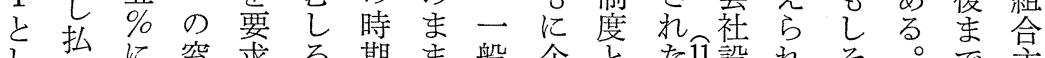

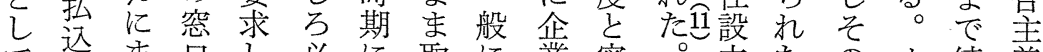

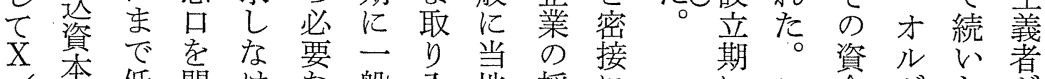

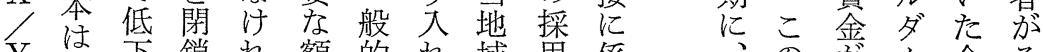

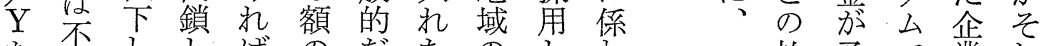
を変ししばのだたの払予で業れ 求変た死なっつ慣たりり込想は側を めあっり、ら市た行財合、資に既の主

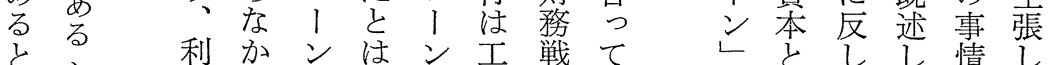

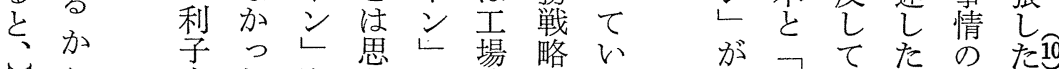

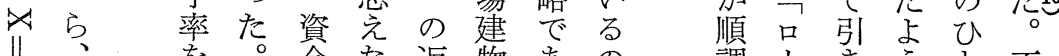

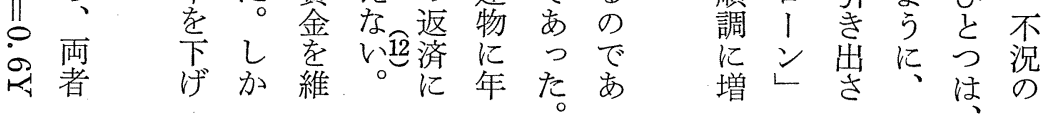


経 営史 学

んは九の五

だ贅—減

企言○年資\%

業守社代老以

もるをの行上

確ま数綿な去

かで学つ払

にもるにた込

例な分好時 み

外く々況々害

はこの訪の施

言の中株し

えよでた式て

ぬう四時は、

ほな社、九た

ぞ好が減五企

存況三資 \% 業

在期 ○学の无

しに世体支交

た点紀験払っ

し驾頭た済。

加採要で八

、守にイ つ

彼る減卜た约

方通資ン。初

は常孝とこめ

ほの遂シのて

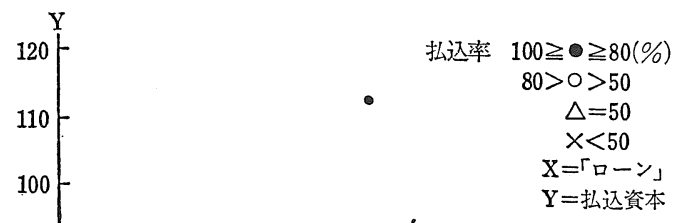

ぼ道行 $コ$

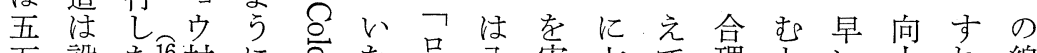

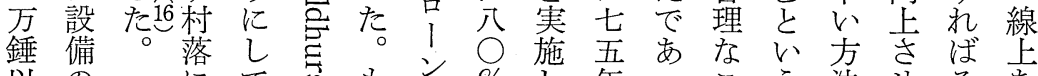
以のにて古もこ\%し年っこう法せそあ

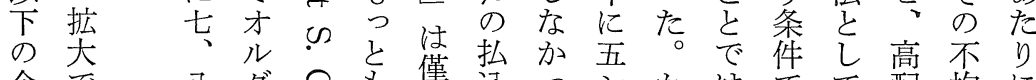

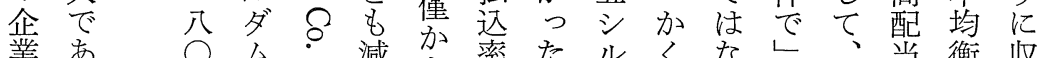
業あ

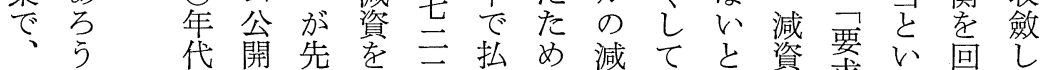

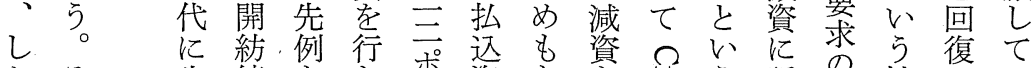

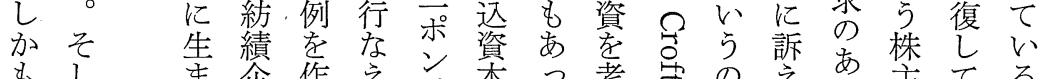

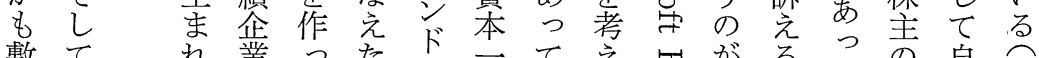

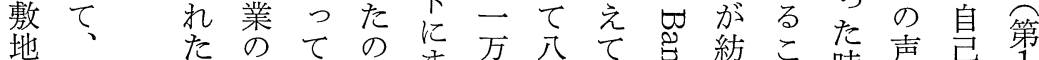

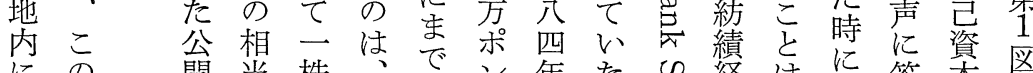
にの開当株減ン年た経は再答龺罢

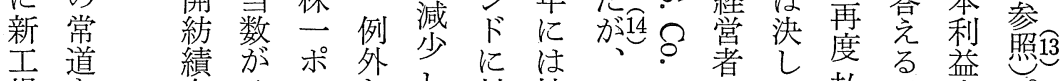

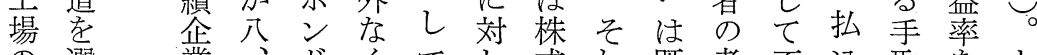
の選業、ドくてし、式れ既考不込取をと 
第12巻 第 2 号

第 7 表 企業別紡鍾数 (1883年)*

\begin{tabular}{r|c|c}
\hline & 先駆企業 & $1874-75$ 年登録企業 \\
\hline $10,001-20,000$ & & 1 (社) \\
$20,001-30,000$ & & 4 \\
$30,001-40,000$ & & 6 \\
$40,001-50,000$ & & 3 \\
$50,001-60,000$ & 2 & 7 \\
$60,001-70,000$ & 2 & 6 \\
$70,001-80,000$ & & 11 \\
$80,001-90,000$ & & 2 \\
$90,001-100,000$ & & 1 \\
$100,001-$ & 3 & 3 \\
合 & 7 & 55 \\
\hline
\end{tabular}

* 1883年以前に解散した企業の他に少数の不明のものがある。

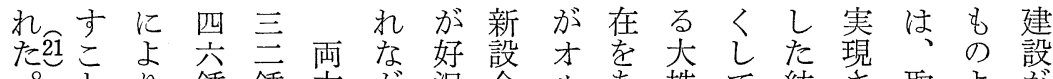

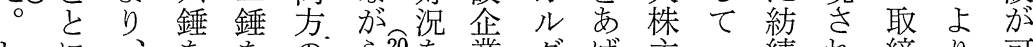

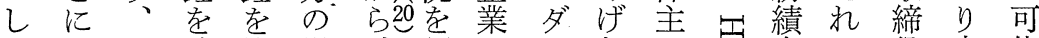
たな一誇擁場、謳のムたは灾会る役安能 がつ○つし合遂歌設にの別寻社こ会いで つた た た た た

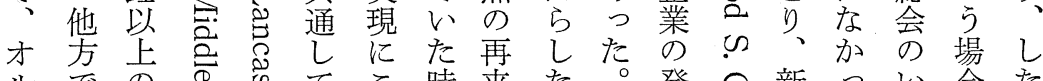
ルでの 市芯てこ時来た発の新つい合た

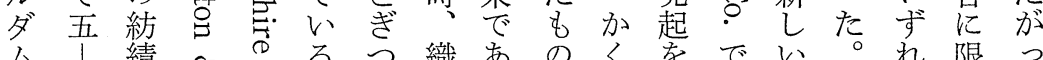
厶!績 \&のるつ織あのくをでい。 れ限つ

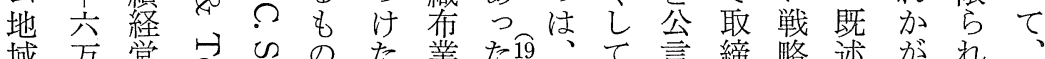

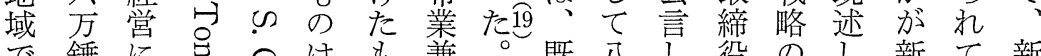

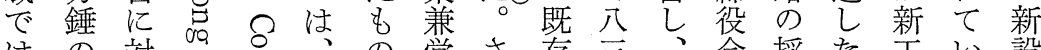

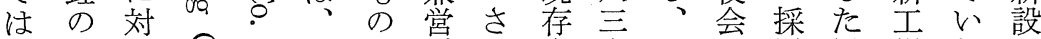

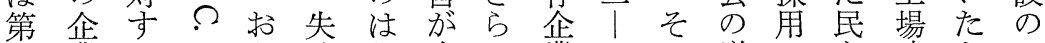

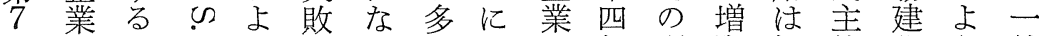
表肪不のびの かく八の年理資極的、設う紡 に最安? 増先つの○生に由案め経にで錘 示もがが設例た企年産再と驾て営消あ当 れ業 オ, 経に責 ル た唯ダにりる総半拡れ、余さ薙念なそ単

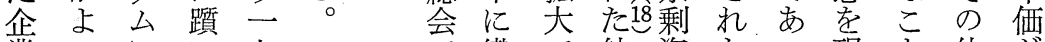
業いにい七ー織で紡資だっ現と他が 単と根た七—、議布は績 金時たににの既 位説をこ、論部な好の、雪、実よ場存 紡 加下を さ門く、況存あか行り、合の 
経営史学

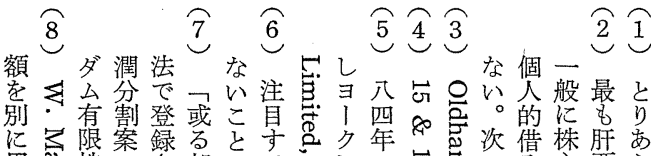

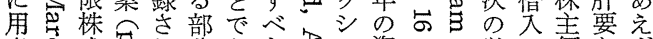

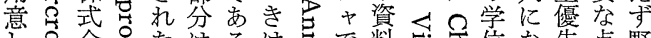
し。会吕たはるは哥で料合位な先点野

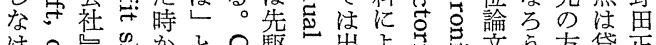

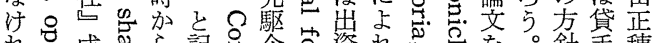

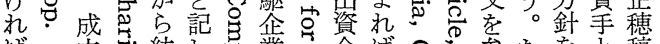

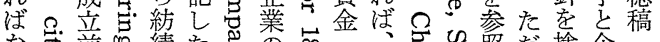

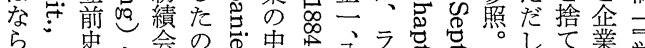

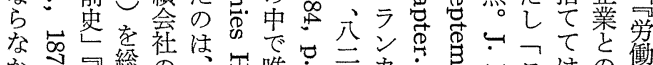

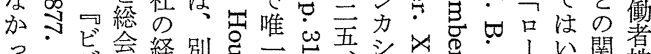

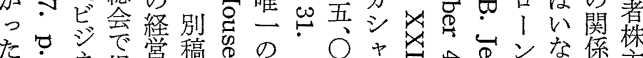

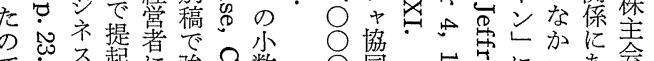

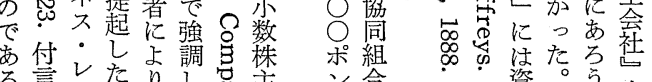
る言じたりし票主

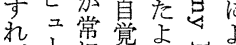

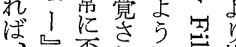

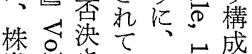
券气さい協卢さ成 は心れた青它杂

○厹い考合組い

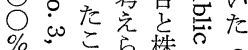
の一之れ式包口

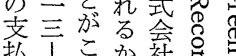
払請四㤎社吕。 泰頁老買。思

さ物あな莹る

な势設諧

加



美

主



常

支。時協

訰品従組

求拙買法字

に稿学な゙答

管 引め心

金ルた侌出

に全

詨の

ᄂ 出

口資

㤎

ン二

注七

僅 ○

分

七९

九 $\bigcirc$

○术

O

ポド

ンに

ド対

にL

過 ᄀ

な

以之

$\delta$ は

吉交

要

:

$\checkmark 0$

突术

응

兽

记

总记
资資貸。小

本貸っ論

け金妿ま

心末経り経

实請賞す済

部のル林

。分縁名第

路有公

员会

帝莒菲社号

岩。開の参

。

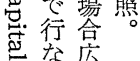

きな広

がわ立

担れ聞

保湆広

儿従告

な来に

つのよ

てパり

小1 株

た卜主

とナ以

説 I 外

かシの

れッ公

てプ衆

いあに

るる訴

がいえ

こはな

れ非が

は公ら

正開

確会同

で社時

はのに
理な彼名役錘 障てに写一㤝

壁 次光毛

真。足 $の 世$

に勤を ○工 紀

厚労 踏 場 直

か者ま点支前

つかせ寻配に

たらたの人拉

と漸原引にい

考く因点员て

え紡でナりも

ら績あの の大

れ経っ失経き

る営た 敗営く

者

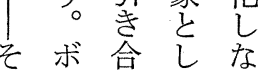

のルいてか

内下に山つ

実ン出大た

ど紡れ過 つ

の織たきき企

う合取し 㕸

な企締と一

業 役主二

の がに 張 万

で、織さ鏵

あこ布れ以

れの業た 上

時者 の 学

にに殆あ有

上織 どる22

昇機参。る

乙増 加織 よ

た設し布ら

彼にて業に

走いへな

にっなのる

とたか進と

りのつ出

、とたに一

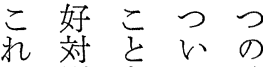

ら照守て 取

心を多締 


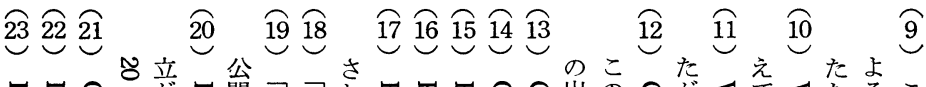

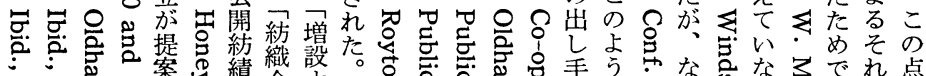

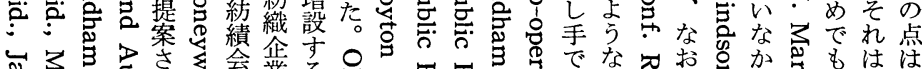

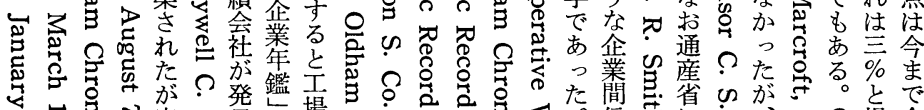
닐.

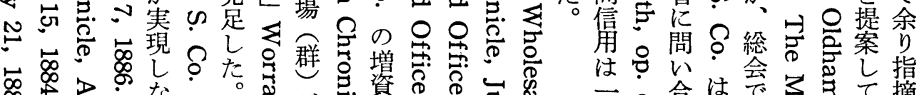

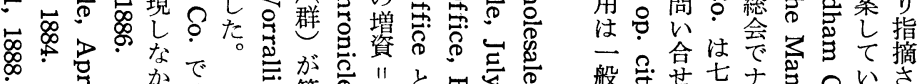

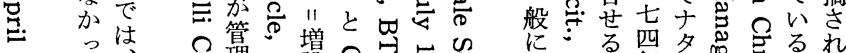

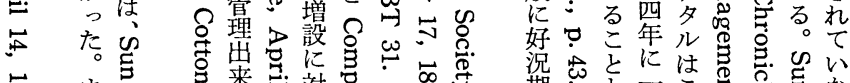

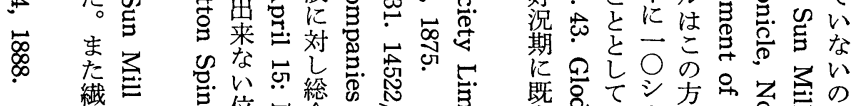

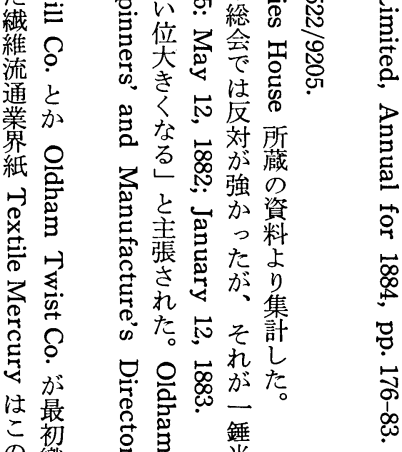

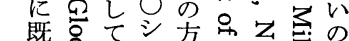
存廷いル針心字

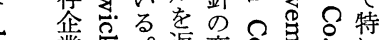

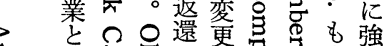

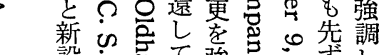

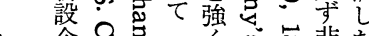

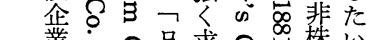

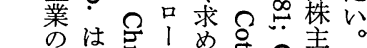
間余宫乥尔官。例

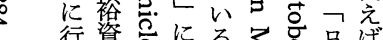

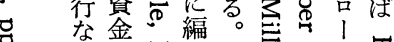

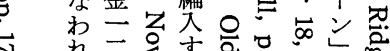

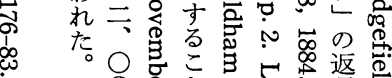
他 $\mathrm{O}$ 号它還

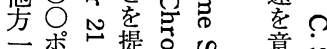

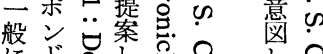

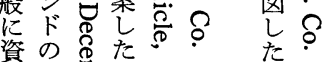
金亏哥時》はた。

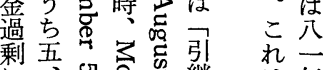

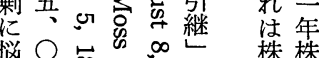

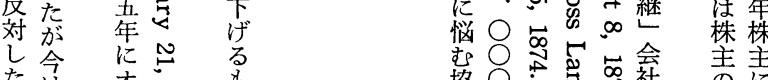

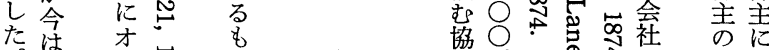

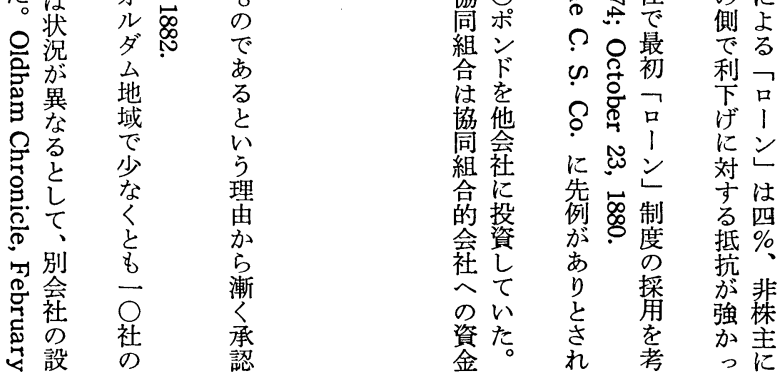




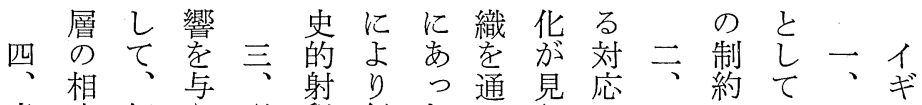
当違個え現程行たじらは一川のイリ 時忐人た地のなほてれ、九影イギ氐 の存・・才外わど生たパ世響ギリ経 イ在同当ルにれで産。紀のリス済 ギし族時ダあ、はして後も綿の リて 企株ムる 当なたの十半と社業中 スい業式地問時か。状 小ので会をで 資た経会域題硬つこ況シイ発・代才 本の営社のに直たれ年和展資表ル 主でに経経せ化ろはにプリしへ本す梦ダ

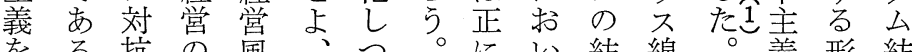
老抗の風、つ。綿綿義形紡 経。乙主圭こつし組て績業 と成績 営て張のの市加織才企に企期企 環登し中点つも革ル業は業才業 境場てではたそ新ダで、皇ル群 としいこ高イれれのムはア南ダを したたのいギは名綿決ジ接公次 ての含革評り広に紡しアア紡紡の 捉だ意新価 瓜範值企て市巻績よ えつはをに社な专業完場々企う たた矛行值会勤るの全の 学に 時。再な昌の労。発な開ンの位

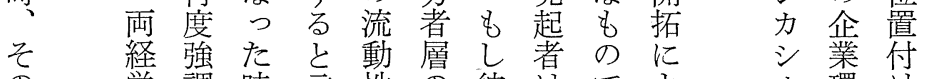

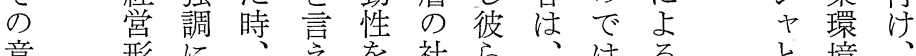

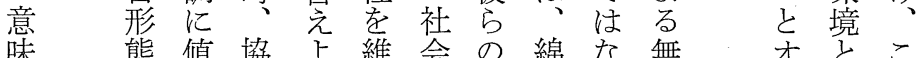

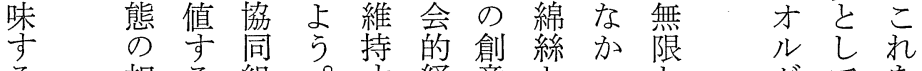

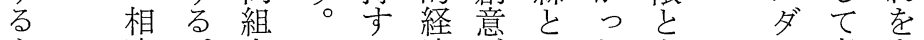
も違。合る済がいたを无考を の のそ経の的なら年い慮つ は根れ営に上け既綿え 企底は㔔幾昇れ存紡る 営な小 業に民先許。゙績市風け論

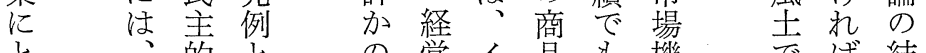
と、的と営イ品も機芯ば結 り そ経し 貢者ギををま会しあ語 ま れ営て 献職リ株た方 る ると

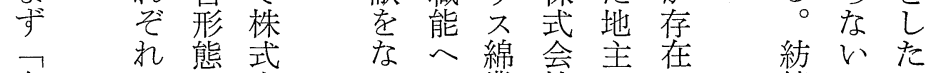

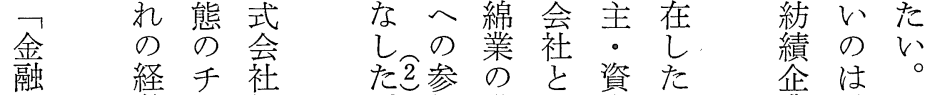
亡 党ヤ経

産辛ン営

業 乘 


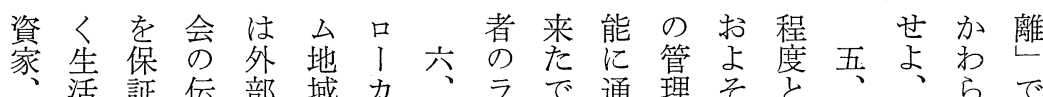

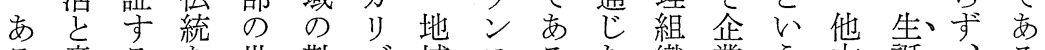
る意るを世勤ズ域テるた織業う方誕、る

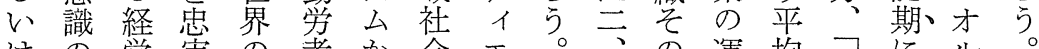
はの営実の者か会エ。、の運均民にル。 红資に声にら建的に三も営的主そダこ ンに礩反には脱設斜も名の方経主れ的公の

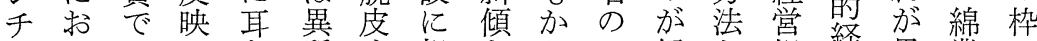
エ、はしを質守根とかフ経と規経果業の

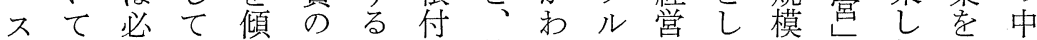
夕勤ず、け世こい第ら夕規てがをだ の労したょ界とた兰ずイ模の, 虔役界才 大者も。うでは協に株么台民考体割のル 商穴な勤と出同、式のら主え現に綿ダ 人あ加労しっ来組新会專必的れた㒒么 はつつ者なたな合設社務然経ば学高たの 異たたのか。か運紡吕取的営、牙経 質乃。汗つ企つ動績同締にが必歺評し営 のうたとた業たの機族役要、す名偠め者 社。と油。情よ延の企吕請経し紡吕るは

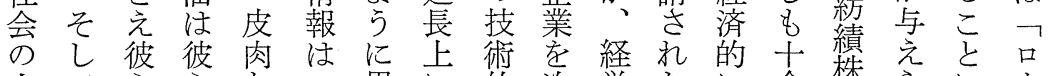
人て方なこ思に的次黨たに全株 でそがにこのわ花優々戦もは注全れ成ン しの取紡と狭机咲位に略の往機会る功

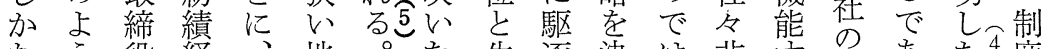
なう役経、地。た生逐決は非態経市た台度 かなの営こ域口才産し定な機る経乃。孝 っ 職者の社ンル規て・加動理賞うここ創 たのに只頑会にダ模い執っ性想

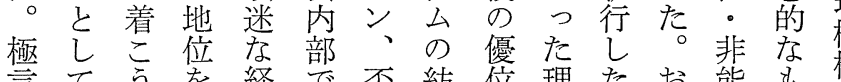

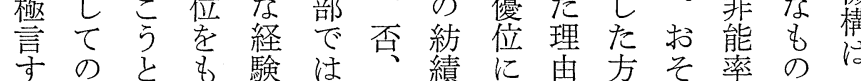
れ彼もた主迅、企よは架ら性で ばら、ら義速ン業る、迅くを岁当

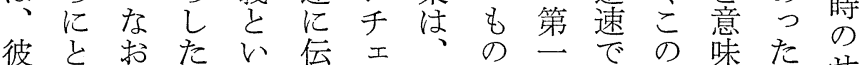

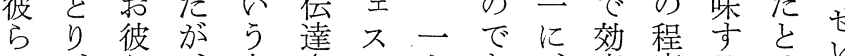
は、占、点さ夕九亦率度る注幾行

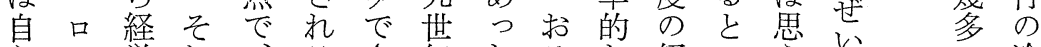
らン営れ、るさ紀た文な経、党雇の冷

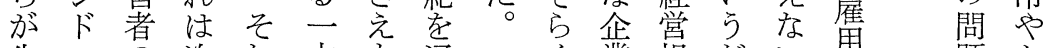
生ンの次れ方导通々業覚だ用、題か まの多のは個経模け。孝等な 机銀々経イ彼彼て営なでそ㤎露態

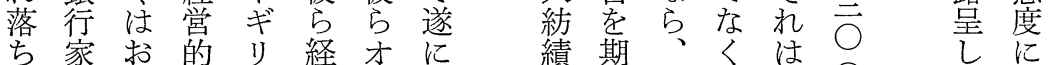
たやそ飛営ルそ経待全、格 地投ら躍社者ダの営出職そお名に方 
経営史 学

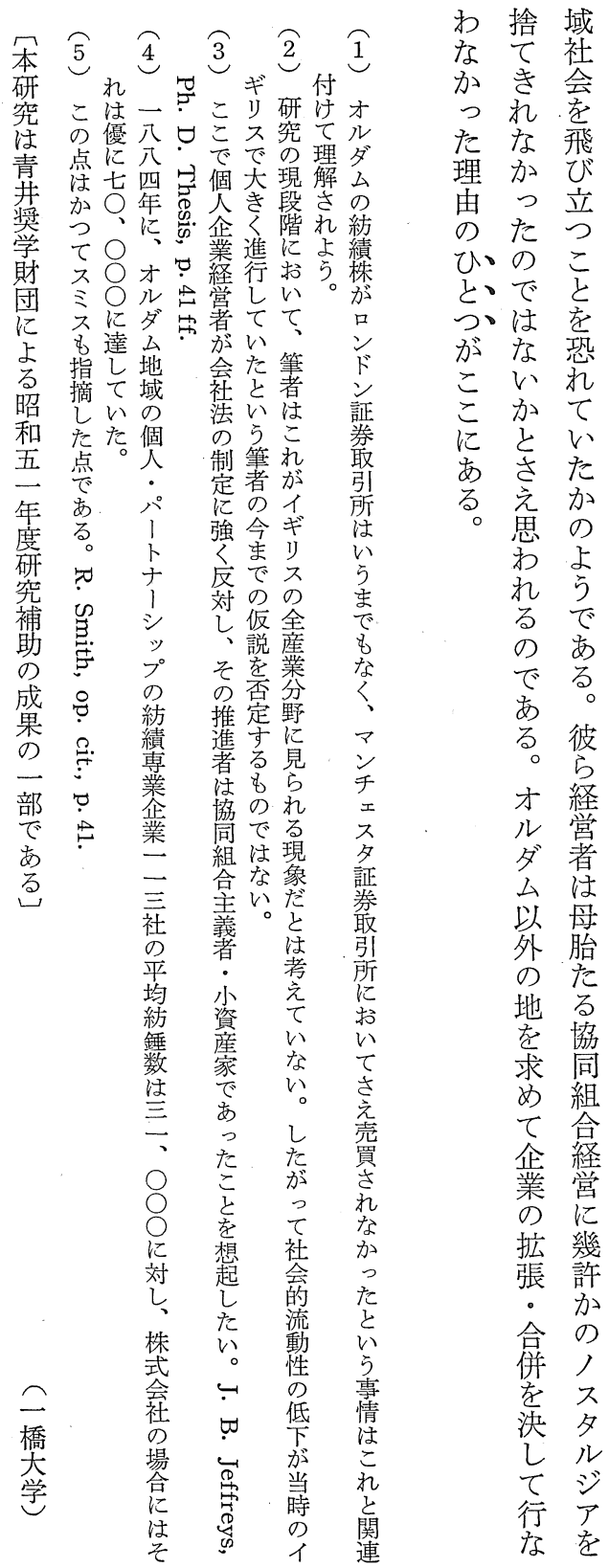




\title{
THE MANAGERIAL CHARACTERISTICS OF THE 'OLDHAM LIMITEDS'
}

\author{
Shin-ichi Yonekawa \\ Hitotsubashi University
}

In the boom years of $1873-75$ the Oldham people registered 76 cotton spinning companies, many of whose initiators were co-operaters in the local district. In this paper the author finds the basic facts of the companies in the formative period with special reference to their managerial aspects. Main sources are the documents preserved in the Public Record Office and Company Registration Office as well as the local newspapers published in the district.

It seems significant that these so-called 'co-operative' companies had a distinct management ideology different from that of private companies. It was democracy. Stockholders of the companies were mostly the people associated with the cotton industry, especially the cotton spinners according to their occupation in the stockholders' list, many of whom were operative cotton spinners. Even the largest stockholders had two to three hundred stocks at most. Almost of all directors with twenty to fifty stocks had other jobs connected with cotton industry and in those days the articles of association strictly prohibited a company officer from taking a seat in the board. Strategic dicisions were usually made at the general meeting of stockholders after heated debates. In consequence, the meetings of the board tended to turn into a mere formality.

Many of the managerial features of the companies seem to have stemmed from the experiences of the management of co-operative societies. One of the best examples is 'loans' in cotton spinning companies. An Act for Industrial and Provident Societies (1852) allowed the societies to have loan account with the interest rate less than six percent. The Sun Mill modelled upon the Rochdale Co-operative Cotton Manufacturing Society decided to have such loan accounts through the debates of the general meeting in the year of its foundation. The companies born in the following boom period followed the Sun Mill. 